SJ Quinney College of Law, University of Utah Utah Law Digital Commons

Utah Law Faculty Scholarship

Utah Law Scholarship

2016

\title{
Drinking from a Firehose: Conversation Analysis of Consultations in a Brief Advice Clinic
}

Linda F. Smith

S.J. Quinney College of Law, University of Utah, linda.smith@law.utah.edu

Follow this and additional works at: http://dc.law.utah.edu/scholarship

Part of the Counseling Commons, and the Legal Profession Commons

\section{Recommended Citation}

Smith, Linda F., "Drinking from a Firehose: Conversation Analysis of Consultations in a Brief Advice Clinic" (2016). Utah Law Faculty Scholarship. 55.

http://dc.law.utah.edu/scholarship/55

This Article is brought to you for free and open access by the Utah Law Scholarship at Utah Law Digital Commons. It has been accepted for inclusion in Utah Law Faculty Scholarship by an authorized administrator of Utah Law Digital Commons. For more information, please contact valeri.craigle@law.utah.edu. 


\section{Drinking from a Firehose: Conversation Analysis of Consultations in a Brief Advice Clinic}

\section{By Linda F. Smith*}

The number of clients representing themselves in family law matters has ballooned in recent years. ${ }^{1}$ To address this situation courts have established self help centers to provide legal information and "brief advice clinics" have been staffed by legal service programs, volunteer attorneys and law students. ${ }^{2}$ Those concerned with access to justice have sought to study the efficacy of such brief information/advice programs through various means. ${ }^{3}$ This is an important endeavor, as most parties are proceeding pro se because they cannot afford an attorney ${ }^{4}$ and the "reduction in funding for civil legal services has resulted in significantly fewer attorneys"

* (CLinda F. Smith, James T. Jensen Professor of Law and Clinical Program Director, S. J. Quinney College of Law, University of Utah. This Article was made possible by a grant from the American Bar Association Litigation Research Fund and the University of Utah S. J. Quinney College of Law Faculty Development Fund. The author wishes to thank Robert Dinerstein, Leslie Pickering Francis, Juan Camilo Lopez, Richard K. Neumann, and Paul Tremblay for commenting on an earlier draft, and her colleagues at the S. J. Quinney College of Law for commenting upon a presentation of these findings. The author is indebted to the Pro Bono Initiative Director JoLynn Spruance, Legal Aid Society of Salt Lake Director Stewart Ralphs, former Family Law Bar Section Chair Louise Knauer, and the many volunteer attorneys and clinic clients for their participation in this study.

${ }^{1}$ See Linda F. Smith \& Barry Stratford, DIY in Family Law: A Case Study of a Brief Advice Clinic for Pro Se Litigants, 14 J. Law \& Family Studies 167, 168-69 (2012). In 1990 in Arizona 88\% of family law litigants were unrepresented, Bruce D. Sales, Connie J. Beck \& Richard K. Haan, Is Self-Representation a Reasonable Alternative to Attorney Representation in Divorce Cases? 37 ST. LouIs. U. L. J. 533, 571, 594 (1993); in 2005 in New York 75\% of parties in Family Court were self-represented, Russell Engler, Connecting Self-Representation to Civil Gideon: What Existing Data Reveal When Counsel is Most Needed, 37 Fordham URB. L. J. 37, 41 (2010); in 2005 Utah divorce filings showed $49 \%$ of petitioners and $81 \%$ of respondents were selfrepresented, Utah Jud. Council Standing Comm. On Res. OF Self-Represented Parties, Final Report: 2006 Survey of Self-Represented Parties in the Utah State Courts 2 (2006) available at http://www.utcourts.gov/resources/reports/ (last visited $1 / 7 / 2016)$

${ }^{2}$ Id. at $170,172-73$.

${ }^{3}$ Id. at 172-80. See John M. GReacen, Self Represented Litigants And Court and LeGal SERVICES Responses to their NEEDS: What We Know 4 - 8 (2002, available at http://www.courts.ca.gov/partners/documents/SRLwhatweknow.pdf (last visited Jan. 7, 2016) ( describing studies done in Florida, Idaho, California, Minnesota, Maryland, Maine, Alaska, Washington, and five jurisdictions by the National Center for State Courts).

${ }^{4}$ Id. at 169 . See Engler supra note 1 at 41 n. 12. 
available to represent low income clients. ${ }^{5}$ Accordingly, how well these brief advice clinics operate significantly determines the public's access to justice.

This paper builds upon a survey of participants at a brief advice family law clinic and is the first study to rely upon Conversation Analysis to provide insight into the actual consultations in a brief advice clinic. The article is first descriptive, illustrating the ways in which pro bono attorneys approach these consultations and provide advice as well as the ways clients share information and solicit advice. The article then turns to critique these consultations.

Both attorneys and clients in the brief advice clinic may feel as if they are drinking from a firehose. The attorneys try to quickly home in on what precise advice and direction the client needs by reviewing documents and asking yes/no and short answer questions. At the same time, the clients often try to give narratives explaining themselves. Attorneys begin to counsel the clients within a few minutes, sometimes before they have learned all the relevant facts that will ensure the advice is applicable. These attorneys, having substantial expertise in family law, provide the clients with a great deal of accurate counseling, often including personalized strategic advice, but sometimes including only information. These are not "simple" cases and the flood of advice leaves one wondering if the clients have understood and will be able to remember it all. This article concludes by setting forth "best practices" for a brief advice clinic based on the evidence provided from these consultations.

\section{DESCRIPTION OF STUDY}

This research began with collecting data about the clients of a brief advice family law clinic and surveying the clients and the advisors about the consultation. ${ }^{6}$

That study revealed the demographics of the clinic patrons and the nature of their issues. A majority lived below the poverty line and $86 \%$ lived below $200 \%$ of poverty; $63 \%$ were women. ${ }^{7}$ Many clients presented more than one legal issue, with custody being the predominant issue $(52 \%)$ but a full range issues being presented: (divorce $41 \%$, child support $37 \%$, visitation $34 \%$, paternity $20 \%$, alimony $16 \%$, child abuse $10 \%$, spousal abuse $8 \%$, guardianship of a child $6 \%$, parental termination $4 \%$, adoption $4 \%$, guardianship of an adult $2 \%$ ). Clients did not present "simple" matters, and many needed to change an order $(28 \%)$ or enforce an order (14\%). 8

5 Conference of State Court Administrators, Position Paper on Self-Represented

Litigation 1 (Gov't Rel. Office ed. 2000), cited in ABA SECTION Of Litigation, HaNdBook on Limited Scope Legal Assistance: A Report of the Modest Means Task Force, 9 (2003) available at www.americanbar.org

${ }^{6}$ Smith \& Stratford, supra note 1.

${ }^{7}$ Id. at 186.

${ }^{8}$ Id. at 187. 
Clients were surveyed as they exited the consultation and then again a few months later. The advisors participating in the clinic were also surveyed about whether they thought the consultation had been helpful.

The exit survey results were very positive: client overall satisfaction was high, the clients felt listened to and believed they had understood their advisors. ${ }^{9}$

\begin{tabular}{|l|l|l|l|}
\hline Exit Questions to Clients & Somewhat & Very & $\begin{array}{l}\text { Combined } \\
\text { positive }\end{array}$ \\
\hline Overall, how helpful was the clinic? & $15 \%$ & $80.7 \%$ & $95.7 \%$ \\
\hline How well did the interviewer listen to you? & $6.1 \%$ & $92.7 \%$ & $98.8 \%$ \\
\hline $\begin{array}{l}\text { How well did you understand what your } \\
\text { advisor told you? }\end{array}$ & $10.0 \%$ & $88.4 \%$ & $98.4 \%$ \\
\hline
\end{tabular}

The advisors (attorneys and law students) also assessed the consultations favorably but somewhat less optimistically. ${ }^{10}$

\begin{tabular}{|l|l|l|l|}
\hline Exit Questions to Attorneys & Somewhat & Very & $\begin{array}{l}\text { Combined } \\
\text { positive }\end{array}$ \\
\hline $\begin{array}{l}\text { Overall, how helpful was the clinic for the } \\
\text { client? }\end{array}$ & $31.2 \%$ & $61.3 \%$ & $92.5 \%$ \\
\hline How well did the client understand the advice? & $30.1 \%$ & $66.4 \%$ & $96.5 \%$ \\
\hline
\end{tabular}

The follow-up survey resulted in clients being less positive, with many clients still being very positive, but the overall positive score dipping lower than the advisors had imagined. ${ }^{11}$

\begin{tabular}{|l|l|l|l|}
\hline Follow-up Survey Questions to Clients & Somewhat & Very & $\begin{array}{l}\text { Combined } \\
\text { positive }\end{array}$ \\
\hline $\begin{array}{l}\text { If you had a new legal problem, how likely } \\
\text { would you be to return to the person who } \\
\text { advised you? }\end{array}$ & $13.3 \%$ & $74.6 \%$ & $87.9 \%$ \\
\hline $\begin{array}{l}\text { How likely would you be to recommend the } \\
\text { Family Law Clinic to someone else? }\end{array}$ & $7.5 \%$ & $84.5 \%$ & $92.0 \%$ \\
\hline
\end{tabular}

Recordings were made over a four-month period, with clients independently deciding whether they wanted their consultations to be recorded. An advertised advantage of having the recording made was that an expert volunteer at the clinic

${ }^{9}$ Id. at 190 and 192.

10 Id. at 210.

11 Id. at 193. 
(the author or an attorney overseeing the clinic) would review the recording within two weeks and re-contact the client if any additional advice should be conveyed. Perhaps for this reason, clients were quite open to being recorded.

Over the study period this research project recorded sixty-three consultations. Twenty consultations were with volunteer attorneys and forty-three were with student volunteers.

After reviewing all the recordings, the author selected four consultations by different attorneys to analyze. The author considered these consultations to be generally successful in that correct and fairly comprehensive legal advice was conveyed to the clients. (This was confirmed by two senior attorneys who oversaw the clinic.) These consulting attorneys all specialized in family law and had been practicing between five and eighteen years, so they had the capacity to provide excellent advice. Three of the four clients' survey results had rated these consultations as very helpful (the fourth client did not complete a survey). The author also considered these consultations to be generally representative of the range of consultations in the clinic, given that each consultation presented different legal issues and three of the four clients lived below the poverty level and one client lived above $200 \%$ of poverty.

These four consultations were transcribed. This article uses conversation analysis approaches to understand and assess these consultations.

\section{APPLIED CONVERSATION ANALYSIS}

Today Conversation Analysis (CA) is the "dominant approach to the study of human social interaction across the disciplines of Sociology, Linguistics and Communication."12 Conversation Analysis is "the close examination of language in interaction," relying upon recordings and transcriptions of those interactions. ${ }^{13}$ Meticulous examination of those transcripts revealed basic truths to the originators of CA:

"[P]eople perform the actions of everyday life by the way they design their turns in the sequential organisation of talk; those turns set up normative expectations on what it is to follow, which fellow-interactants abide by or flout; and the analyst's job is to find evidence for varieties of turn-design, sequences and the

\footnotetext{
12 Tanya Stivers \& Jack Sidnell, Introduction in THE HANDBOoK OF CONVERSATIONAL ANALYSIS 1 (Jack Sidnell \& Tanya Stivers, eds., 2014). ${ }^{13}$ Charles Antaki, Six Kinds of Applied Conversation Analysis IN APPLIED Conversation ANALYSIS: INTERVENTION AND CHANGE IN INSTITUTIONAL TALK 1-2 (Charles Antaki ed., 2011).
} 
actions they perform by looking to the internal construction of turns and the way in which the next speaker orients to the talk that has gone before."14

The originators of CA initially sought to study conversation in its own right, and this has been termed "pure CA."15 Later scholars of CA have also focused their attention on "institution-based materials such as meetings, courtroom proceedings and various kinds of interviews. Their general purpose was to 'apply' the acquired knowledge of conversation analysis to these institutional interactions to show how these institutions were 'talked into being.' ..."16 This later approach is often referred to as "applied conversation analysis."17

There are a wide variety of ways in which Conversation Analysis had been and is applied in institutional settings. Approaches that could be relevant to legal institutions include "Social Problem Applied CA," "Institutional Applied CA" and "Interventionist Applied CA."18 Social Problem Applied CA seeks to shed light on social problems such as conflict, power, gender, and so on by analyzing conversations through such lenses. Institutional Applied CA studies "routine institutional talk - the way that the business of the doctor's clinic, the classroom, the interview and so on is carried out." ${ }^{19}$ Typically this approach does not seek to solve the institution's problems, but to see and describe "how the institution manages to carry off its work. ..."20 Interventionist Applied CA does seek to address some identified problem in the functioning of an institution through "the analysis of the sequential organization of talk." 21 This article will incorporate elements of Institutional Applied Conversation Analysis, using transcriptions from the Clinic to describe its operation, and of Interventionist Applied Conversation Analysis, making suggestions regarding ways to improve the operation of the Clinic. This author has previously written about the benefits of using social science insights to study attorney-client talk, ${ }^{22}$ and used Applied CA to study student-actor legal interviews, ${ }^{23}$ attorney-actor legal interviews, ${ }^{24}$ and an attorney-client interview. ${ }^{25}$

14 Id. at 2.

15 Paul Ten Have, Doing Conversation Analysis: A Practical Guide, 8 (1999).

16 Id.

17 Id.

18 Antaki supra note 6 at 3, 6-9.

19 Id. a 6.

20 Id. at 7

${ }^{21} I d$. at 8.

22 See Linda F. Smith, Client-Lawyer Talk: Lessons from Other Disciplines, 13 CLINICAL L. REV. 505 (2006).

${ }^{23}$ Linda F. Smith, Interviewing Clients: A Linguistic Comparison of the "Traditional" Interview and the "Client-Centered" Interview, 1 CLINICAL L. REv. 541 (1995).

${ }^{24}$ Linda F. Smith, Was It Good for You Too? Conversation Analysis of Two Interviews, 96 Ky. L. J. 579 (2007-2008).

${ }^{25}$ Linda F. Smith, Always Judged - Case Study of an Interview Using Conversation Analysis, 16 Clinical L. ReV. 423 (2010). 
The author consulted Gail Jefferson's transcription methods and utilized the conventions of representing talk "as it is produced" (though with proper spellings). ${ }^{26}$ The reader should be aware that transcriptions made for CA, representing talk "as it is produced," do not look orderly like the imagined conversations included in interviewing and counseling texts, or like the script for a play or even like a deposition transcript. These CA transcripts identify overlapping talk with brackets, identify passive listening back channel cues with parenthesis ("uh-huh," "I see"), identify pauses with a series of periods (one period per second), identify emphasis with bold print and identify actions <e.g. laughter $>$. Occasionally utterances are italicized in order to focus on them in the analysis. The italics do not indicate that there was any oral emphasis.

\section{INTRODUCTIONS AT THE FAMILY LAW CLINIC}

Upon arriving at the Family Law Clinic each client is given a form that describes the clinic and asked to sign a form consenting to the limited scope services. The form then asks for identifying information, provides "check off" boxes for the client to characterize the situation (e.g. divorce, paternity) and the client's goals (e.g. general information, review a document), and invites the client to give a brief narrative. The form asks the clients:

- "What happened? Briefly describe what has happened that brings you to the Clinic."

- "How can we help? Briefly describe what questions you have and/or the help you think you want."

The clients complete these forms while waiting to be seen. Then these forms are given to the advisors immediately prior to the consultation. Accordingly, the advisors should be "introduced" to the clients and the clients' concerns initially through this form.

The counselors all wear nametags, giving their first names and identifying them as either an "Attorney" or a "Law Student."

The oral openings from the four recordings are succinct and focused. In all four cases the client has brought a companion to the interview, and in three the companion is present at the outset and participates in the introduction.

${ }^{26}$ See Alexa Hepburn \& Galina B. Bolden, The Conversation Analytic Approach to Transcription in The HANDBOOK OF CONVERSATION ANALYsis 57-67 (Jack Sidnell \& Tanya Stivers, eds., 2014), and H. Sacks, A. E. Schegloff \& G. Jefferson, A Simplest Systematics for the Organization of Turn-Taking for Conversation 50(4) LANGUAGE 696 (1974). The author chose not to include the many other transcription conventions such as speed, tempo, pitch etc., as not significant in this applied analysis of a legal clinic. 
In one consultation the attorney begins by introducing herself and attempting to confirm the client's name and the topic of the interview based upon the form. This introduction also involves confirming exactly who is a part of the client "team."

$\begin{array}{ll}\text { Attorney } & \text { I'm Laura and I'm an attorney ... and you are Diane and . } \\ & \text {.you're here for a divorce? } \\ \text { Client } & \text { Yeah } \\ \text { Attorney } & \text { And you're? } \\ \text { Companion } & \text { her sister } \\ \text { Attorney } & \text { Okay great. It's great to have support in these } \\ & \text { [situations <laughing >.]. } \\ \text { Client: } & \text { [I just have some questions.] }\end{array}$

In the second interview the attorney is introduced by the researcher and then eases into the interview by introducing her law student observer (who does not speak) and asking for an introduction of the client and the person the client has brought with her.

$\begin{array}{ll}\begin{array}{ll}\text { Ms. Attorney } \\ \text { Client }\end{array} & \text { Hi } \\ \text { Ms. Attorney } & \text { Hello a law student and I was an available lawyer so } \\ & \begin{array}{l}\text { that is why I got that. So, please, tell me, who am I } \\ \text { talking with? }\end{array} \\ \text { Client } & \text { I'm Addie } \\ \text { Ms. Attorney } & \begin{array}{l}\text { Hi Addie, and you are appropriately dressed for the } \\ \text { day. <client was apparently wearing green for St. }\end{array} \\ & \text { Patrick's Day> } \\ \text { Client } & \text { <laughs> That's right } \\ \text { Fiancé } & \text { And Nate } \\ \text { Attorney } & \text { Nate. And how are you two related? } \\ \text { Fiancé } & \text { We are going to be getting married. } \\ \text { Attorney } & \text { Oh congratulations. } \\ \text { Fiancé } & \text { Thank you } \\ \text { Attorney } & \text { And are you engaged yet? } \\ \text { Fiancé } & \text { Yes }\end{array}$

In the third consultation there are two attorneys as well as the client and a companion. The attorneys do not rely on the form but on oral introductions, made with a number of overlaps. These introductions precede any mention of the client's matter.
Ms. Attorney 1
Okay.
Vic
Hello.
Ms. Attorney 1
[Well I'm Sara]
Ms. Attorney 2
[I'm . .] 


$\begin{array}{ll}\text { Vic } & \text { I'm Vic } \\ \text { Ms. Attorney2 } & \text { Heather } \\ \text { Attorney2 } & \text { What was your name? } \\ \text { Vic } & \text { Vic } \\ \text { Ms. Attorney1 } & \text { [Vic] } \\ \text { Ms. Attorney 2 } & \text { [Vic] } \\ \text { Vic } & \text { Like Victor } \\ \text { Ms. Attorney } 1 & \text { And what is your name? } \\ \text { Girlfriend } & \text { [I'm Tina] } \\ \text { Vic } & \text { [This is Tina] my girlfriend. } \\ \text { Ms. Attorney1 } & \text { Hi Tina. So we're Sara and Heather and we're both attorneys. } \\ & \text { And, }\end{array}$

In the fourth consultation the attorney makes polite comments about the client having a lap top, then asks a maximally open question about the client's matter, followed by a partial introduction to confirm the client's name, but not his own:

\begin{tabular}{|c|c|}
\hline Host & Do you want to just stay here? \\
\hline Mr. Attorney & $\begin{array}{l}\text { Yeah, that's actually perfect if you're comfortable with that, I'm } \\
\text { comfortable with that }\end{array}$ \\
\hline Mr. Attorney & Oo. got your laptop, nice. With some internet \\
\hline Client & $\begin{array}{l}\text { So, um, what can I help you with? I'm an attorney, not just a law student. } \\
\text { [Okay.] }\end{array}$ \\
\hline Mr. Attorney & [I shouldn't say just,] they're really good at this. \\
\hline Client & Should I move back? \\
\hline Mr. Attorney & $\begin{array}{l}\text { Yeah, you probably should. I've got a pen in my pocket and then I sat on it. } \\
\text { There we go. }\end{array}$ \\
\hline Client & Ha. $<$ laughs $>$ \\
\hline Mr. Attorney & Okay, is it Dolly? \\
\hline Client & Polly \\
\hline Mr. Attorney & Polly ... What can I help you with? \\
\hline
\end{tabular}

When these encounters are compared to the texts recommending interviewing techniques, one notes the degree to which "chit chat" or informal "ice breaking"27

27 Binder, Bergman, Price \& TREmblay, LaWyers as Counselors: A Client-CEnTERED APPROACH ( $2^{\text {nd }}$ ed., 2004) discusses "icebreaking" and "chit chat" at 83; ElLMAN,

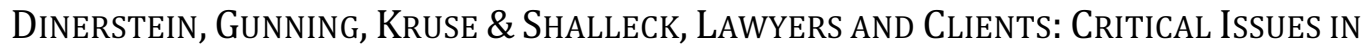
INTERVIEWING AND COUNSELING (2009) notes that "Introductions and Greetings will include introductions and whatever 'small talk' that can help make a client comfortable." at 19. Herman \& CARY, A Practice ApProaCh to Client InTERVIEWInG, Counseling and Decision-Making: For Clinical Programs and Practical Skills Courses (2009) note "At the outset of a meeting it is sometimes appropriate to engage in 'small talk' to put the client at ease" at 18. KRIEGER \& NEUMANN, ESSENTIAL LAWYERING Skills: Interviewing, Counseling, Negotiation, and Persuasive Fact Analysis $\left(5^{\text {th }}\right.$ ed., 
conversation is minimized. Only two consultations involve a turn that could be labeled "ice breaking" - one attorney comments that the client having a laptop was "nice" and a second attorney comments upon the client being dressed for St. Patrick's Day. However, these succinct introductions nevertheless include some personal empathic responses, as when one lawyer confirms "it is great to have help in these situations," and a second lawyer extends "congratulations" on the client's engagement.

When a second person is present, these lawyers are quite direct in asking who the second person is or his relation to the client. It is noteworthy that all four recorded interviews involved clients bringing companions to the brief advice clinic. One imagines that this may be because the clients, promised only brief advice, wish to ensure that they understand everything and ask about everything.

\section{CONFIDENTIALITY \& ATTORNEY-CLIENT PRIVILEGE}

Texts typically teach that the lawyer should explain confidentiality to the client and interview the client in a private setting so that the conference will also be privileged. ${ }^{28}$ Despite the presence of a non-client in all four consultations, only one of the attorneys addressed the issue of confidentiality/privilege.

In the interview with Addie and Nate on St. Patrick's Day, immediately after the excerpt above asking about their engagement, the following exchange takes place:

$\begin{array}{ll}\text { Ms. Attorney } & \text { Okay. I just need you to know that when a person talks to a } \\ & \text { lawyer, the conversation is confidential, it's called 'privileged.' If a } \\ \text { third person is present, that breaks privilege. So there may be } \\ \text { some questions she wants to ask me or that I might want to ask } \\ \text { her that I would not want you to hear the answer to because I } \\ \text { would want them to maintain confidentiality. I don't know if it's } \\ \text { going to happen, but for example, if I had reason to think you } \\ \text { might be in the United States illegally, I wouldn't ask you that } \\ \text { with you listening. } \\ \text { Great } \\ \text { Addie } & \text { You see what I mean? } \\ \text { Ms. Attorney } & \text { Right } \\ \text { Addie } & \text { Okay } \\ \text { Nate } & \text { So if you have no objection } \\ \text { Ms. Attorney } & \text { No } \\ \text { Addie } & \end{array}$

2015) note "In some parts of the country, 'visiting'-comfortable chat for a while on topics other than legal problems - typically precedes getting down to business. In other regions, no more than two or three sentences might be exchanged ... like whether the client would like some coffee" at 102.

${ }^{28}$ See Binder supra note 27 at 106, Ellmann supra note 27 at 251, Krieger supra note 27 at 102, and Herman supra note 27 at 18-20. 


$\begin{array}{ll}\text { Ms. Attorney } & \text { It is fine for him to be here. } \\ \text { Addie } & \text { Right } \\ \text { Ms. Attorney } & \text { Okay? Just know that there might be some issues that come up. } \\ & \text { And it's nothing personal. } \\ \text { Nate } & \text { Oh of course. } \\ \text { Ms. Attorney } & \text { I'm saying this. Is that okay with you? } \\ \text { Nate } & \text { That's fine }\end{array}$

This appears to be a fairly thorough explanation about why the attorney might need to conduct some portion of the interview in private, without the presence of the client's fiancé and a polite inquiry about understanding and consent to this arrangement from both the client and the fiancé.

However, this attorney might well have been justified in treating both individuals as clients without any conflict of interest, as they were there to inquire about Nate, as a stepparent, adopting Addie's child. Had the attorney focused on Addie's intake form identifying the stepparent adoption goal prior to the introduction, the attorney might have realized that both individuals could be considered clients.

The other three interviewers did not discuss confidentiality or privilege at any point.

\section{INTERVIEWING}

Texts that teach about legal interviewing posit the on-going attorney-client relationship rather than the brief advice clinic. While the recommended structure of the interview varies somewhat, all texts recommend a client-directed narrative to identify the client's problems and concerns, followed by attorney questioning to further explore facts and goals. ${ }^{29}$ All texts consider ways to develop attorney-client rapport and recommend reflection or active listening. ${ }^{30}$

\footnotetext{
${ }^{29}$ Binder supra note 27 at 86, 112-148, 149-202 recommends "preliminary problem identification" followed by a "time line" and "theory development questioning"; Ellmann supra note 27 at 20 recommends the client being allowed "to describe her problem and related concerns" followed by "fact exploration" where the lawyer asks more detailed questions; Herman supra note 27 at 19-20 recommends first inviting "the client to tell his story" and then "prob[ing] his objectives or goals"; Krieger supra note 27 at 102 recommends giving the client "full opportunity to tell you whatever the client wants to talk about" before structuring the "informationgathering" with questions.

30 Binder supra note 27 at 41-63 discusses "active listening"; Ellmann supra note 27 at 27-33 recommends "creating connection" with the client through active listening, reflecting, validating and empathy; Herman supra note 27 at 28-30 recommends conveying empathic understanding and engaging in active listening; Krieger supra note 27 at 97 - 100 recommends "active listening."
} 
Despite the wide-spread use of forms in which clients provide information about themselves and their situation ${ }^{31}$, instructional texts do not address how the use of such forms should relate to the attorney-client conference. ${ }^{32}$

The clients in the Family Law Clinic are asked to introduce their problems and goals in writing on the intake forms before they confer with an attorney. One would expect the contents of the form to have an effect on the content of the consultation. At a minimum the attorney might know the type the case the client thought was involved. Depending upon the details provided to the "what happened" and "how can we help" questions, one might imagine that the client's oral narrative would be shortened and the attorney's questioning affected.

\section{A. Diane's Divorce}

In Diane's divorce case, the intake form has provided the following information:

What happened? Briefly describe what has happened that brings you to the clinic:

Spouse - walked out after 18 yrs marriage. 20 yrs together. He left and taken no responsibility at all. Only sees the kids when he wants. Said he would finish paying rent on Apt. till lease was up (6 mo) and the next mo couldn't pay rent. We had to leave the apt with nowhere to go.

How can we help? Briefly describe what questions you have and/or the help you think you want.

Anything about Divorce \& my rights.

Why I don't qualify for Legal Aide.

This client has provided a heart-wrenching narrative in her Intake Form, highlighting her husband's abandonment of her and their children, his failure to support them and their eviction with "nowhere to go." She has also indicated a desire to be represented in asking about Legal Aide, rather than to proceed pro se.

${ }^{31}$ An internet search for "law firm intake forms" will yield many sample forms and advice about their use, for example see Gyi Tsakalakis, Client Intake Resources (2012) on lawyerist.com available at: https://lawyerist.com/39275/client-intakeresources/ last visited December 29, 2015. Also see: http://www.americanbar.org/groups/gpsolo/resources/solosez/popular_threads_ 2011/072111Thread4.html last visited December 29, 2015.

${ }^{32}$ Binder supra note 27 at 81-82 mentions pre-initial meeting communications by telephone or electronically, but does not address intake forms; Krieger supra note 27 at 96 posits a secretary discovering the "subject of the interview" in a telephone conversation; Herman supra note 27 at 16-17 similarly suggests a secretary or the attorney screen the client by telephone. 
The attorney has obviously read the form as in the introduction (see above) she confirms the client's name and that "you're here for a divorce" but does not reference or acknowledge the written narrative. After the introduction, the client indicates a desire to have her questions answered rather than to provide a further narrative. The conversation continues as follows:

Diane [I just have some questions.]

Ms. Attorney Okay, so it looks like you're interested in getting a divorce?

Diane Yeah.

Ms. Attorney Tell me where you're at in the process?

Diane Clueless.

Ms. Attorney Okay <chuckles>

Diane Yeah.

Ms. Attorney Has anything been filed at all?

Diane No.

Ms. Attorney Okay.

Diane No, I can't figure out where to go or how to go about it.

Ms. Attorney Okay.

Sister I would like to know why she doesn't qualify for legal aid?

At this point the client's sister interjects the second goal - getting represented by Legal Aid - and the attorney turns to provide information about handling a divorce pro se or seeking free legal services.

Sister I would like to know why she doesn't qualify for legal aid?

Ms. Attorney Um uh d you apply for legal aid and was turned down?

Diane Yeah.

Ms. Attorney Okay, that's something that I would recommend you talking with them, they should be able to give you an answer to that. I, my, my very best guess is that you wouldn't qualify because of income. That's how they they figure it out. So, but you can call them to ask. I don't know their policies. But, so you at least you can check one thing off your list that you at least applied for legal aid. Cause that's the first thing. So I'm sorry that you didn't qualify. But there are several other options for you, okay? Um one of them that I'll go over is there, there's forms available online. Have you heard about that?

Diane Yes and no <chuckles $>$.

Ms. Attorney Okay, so it's called the online court assistance program. And the website is UTcourts-

Here the lawyer begins to provide advice only 42 seconds into the consultation. 


\section{B. Addie's Stepparent Adoption}

In Addie's case her intake form had checked off the following boxes regarding "legal matter" or "kind of legal issue (mark all that apply)":

- Adoption

- Custody

- Name change

- Termination of parental rights

The form also addressed "Type of Help - The kind of legal help I want is:" and Addie had checked off:

- Particular instruction about how to do something in my case (e.g. how to 'serve' a document)

Her intake form also provided the following information:

What happened? Briefly describe what has happened that brings you to the clinic:

Get paternal rights taken away so my future spouse can adopt my daughter and get her name changed.

How can we help? Briefly describe what questions you have and/or the help you think you want.

How I can go about this without hiring a lawyer / what paperwork I need to do.

Note that the client has twice focused on her goals and has not provided any narrative as to "what happened" on the form.

After the introduction and discussion of confidentiality, this attorney begins by referencing the checked "type of legal help" from the form and then turns to ask specific questions relevant to a birth father's rights, terminating those rights, and seeking a stepparent adoption.

Ms. Attorney Okay you need help with 'how to do something in my case.'

Who is the other part of your case?

Addie Well I have a child by somebody else.

Ms. Attorney You have a child, and has paternity been decided?

Addie Well it was out of marriage but he signed the waiver in the hospital so his name is on the birth certificate.

Ms. Attorney Out of marriage, does he, you have a natural child, but he did acknowledge paternity?

Addie Right.

Ms. Attorney That's important because just putting his name on the birth certificate is not enough. So he signed papers in court so he is acknowledged as the legal father? 
Addie Right.

Ms. Attorney Okay, what, what is your child's name?

Addie Jasmine.

Ms. Attorney Jasmine? How old is Jasmine?

Addie Six.

Ms. Attorney Oh okay, and who does Jasmine live with?

Addie Me.

Ms. Attorney Oh okay, does he pay child support?

Addie No, he is in jail.

Ms. Attorney Well was he ordered to pay child support?

Addie Yes.

Ms. Attorney And did you go through ORS or did you go through the courts?

Addie ORS.

Ms. Attorney So ORS sent a child support order and was he paying before he went to jail?

Addie He's never paid.

Ms. Attorney Oh that's, interesting! So you have Jasmine, how long has he been in jail? Jasmine is six.

Addie Um I think a year now. Going on a year.

Ms. Attorney Now before the year, how often did he see Jasmine?

Addie Once, I think he has seen her three times her whole life.

At this point, 2 minutes and 40 seconds into the consultation, the attorney turns to provide the legal advice requested. The attorney has asked seven narrow questions and six yes/no questions (two of these confirming a prior answer) to understand the legal rights of the father and to assess the viability of terminating his parental rights.

\section{Enforcing / Modifying Vic's Visitation}

As soon as the introductions (above) are concluded Ms. Attorney \#1 takes the client's intake form and begins to read from it. The form indicates the "type of legal matter / legal issue" is "child support" and "visitation" and the "type of help" needed is "general information about the law, my rights, my responsibilities." It states the "opposing party" is "ex-wife" and provides the following narrative and requests:

What happened? Briefly describe what has happened that brings you to the clinic:

For denial of parent time and child support issues. Unwilling to work with child support.

How can we help? Briefly describe what questions you have and/or the help you think you want. 
What can I do about getting my supervised visits taken off my divorce decree?

Suggestions on how or what to do in court in a month when I go back to see

what I can get my visitation. What rights do I have.

Note that as with the Stepparent Adoption case, the client provides topics and goals, but not a narrative about "what happened" on the Intake Form.

Ms. Attorney 1 [Hi ]Tina. So we're Sara and Heather and we're both attorneys. And,

Vic Okay

Ms. Attorney 1 so what we need is this right here. Okay. I will sign it . . . . . .

Vic May we begin?

Ms. Attorney 1 Okay, so what have you got going here?

Vic [Child support]

Ms. Attorney 1 [Child support]

Vic [Visitation]

Ms. Attorney 1 [Visitation] Parent time. General information about the laws. What you need. Hmm oh, you've got supervised visits on your divorce decree?

Vic I've never had them. But I've had them at the point, she never enforced them until just recently.

Ms. Attorney 1 Okay, why don't you show me the paperwork you have?

Girlfriend He's already filed a motion, (oh good) and he has a hearing date.

Ms. Attorney 1 Oh excellent.

Vic That's uh, the first one, babe?

Girlfriend Yeah, the first uh manila envelope.

Ms. Attorney 1 It says that the hearing is on Friday, February $10^{\text {th }}$ ?

Vic No, that's the next one.

Girlfriend She didn't show. Well her attorney I guess dropped counsel and didn't notify the court.

Vic She didn't show to that one

Ms. Attorney 1 Oh I see.

Girlfriend Yeah, so we had to set a new date.

Ms. Attorney 1 So March $10^{\text {th }}$ is your date, and your commissioner is Thomas who is a great commissioner.(Good) So let's take a look at.

Vic I think it's in there.

Ms. Attorney 1 Okay. So here's your motion . . . Okay, so you're saying that you guys agreed to something in your mediation session?

Vic Yeah, I have a mediation memorandum right here, this is everything that was agreed to.

Ms. Attorney 2 [inaudible] Sorry, seem like kind of an awkward little.

In this case, the client has already filed papers and is now looking for guidance about "what to do in court" during the hearing that has been scheduled. Accordingly, the attorneys begin by reviewing the papers to see what they are, what the client asserts has happened, and what remedy the client has sought. After this review of documents, Attorney \#1 addresses a few focused questions to the client: 


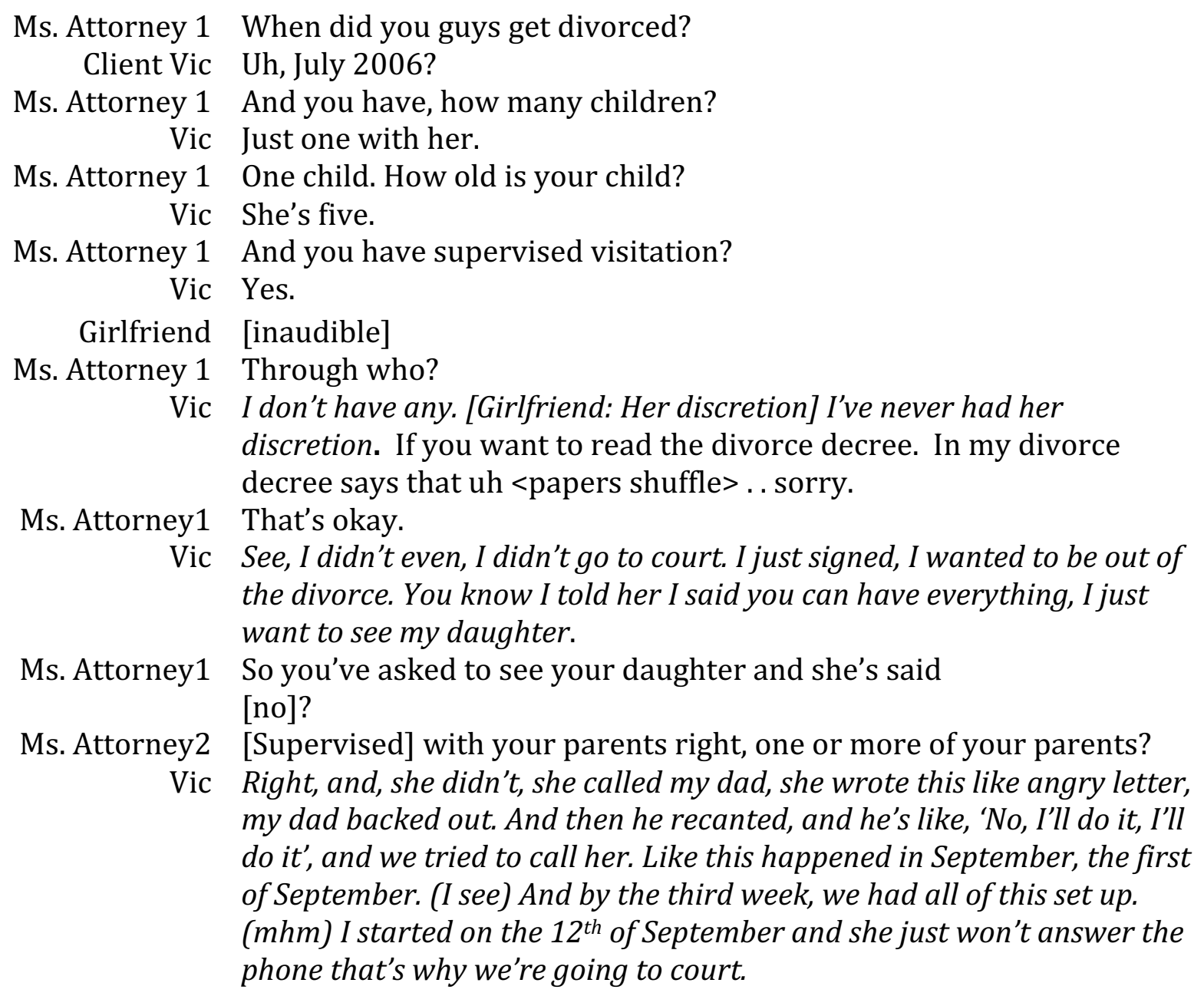

Although the Attorneys' questions call for short answers (asking for the name of the supervising agency; asking the bottom line question "so you've asked to see your daughter and she's said no"), the client Vic appears to want to tell his story and inserts narratives when he is able (see italicized exerts above). He tries to explain that though the divorce decree calls for supervised visits his visitation has never actually been supervised; to explain his reason for agreeing to her demands at the time of the divorce; and to recount what he has done to try to arrange for supervised visits in the past few months.

At this point ( 3 minutes and 20 seconds into the consultation) Ms. Attorney \#1 expresses her opinion about the client's case:

Attorney 1 Yeah, this makes sense, you're doing the right thing.

Then Ms. Attorney \#2 poses some additional questions to understand the status of the mediated agreement: 
Ms. Attorney 2 Yeah, um, and so, your .. parent-time is supposed to be alternating weekends (yes) and one additional day each week for a few hours.

Vic Yes, I had all of this and just recently.

Ms. Attorney 2 Supposed to be supervised by your parents until A, B, and C happen, right?

Vic Yes, this was our mediation but she didn't file, she didn't do any of it. [I didn't get a single visit.]

Ms. Attorney 1 [You didn't get a single visit.] Are you employed right now Vic?

Vic Yes I am. (Great) And then uh, so I uh-it happened on the 1st, and by the 3rd, she'd recanted all that and she didn't want to do nothing so. Like, this happened on Wednesday and by Friday, she didn't want to do nothing. She wrote this real angry letter to my family and said all kinds of crazy stuff.

Ms. Attorney 2 So what you're saying is that this agreement was never formalized, (never formalized) because you filed it with the court but she never responded?

Vic Yeah. She never responded. She came, we did the four hours and she never showed up.

Girlfriend Well, she signed it there though, didn't she? Or no?

Vic Well she agreed to it, and by Friday I went to sign out.

Ms. Attorney1 So you didn't ever write it up?

Vic No, she had all this information, she had this information mailed to her through um the mediation coordinator Nancy McGahey. And all these and so this next week she was going to come up and see the place and everything and

Ms. Attorney1 It just all fell apart. So it never got written up [and finalized?]

Vic [Never got written up]

Here again, the attorneys are trying to pin down the exact procedural posture by asking yes/no and short-answer questions, and Vic (see italics) is trying to tell his story of everything that when on. After the attorneys believe they have understood the facts, the attorneys again (at 4:44) turn to provide the client with a general positive assessment of the work he's done so far.

Ms. Attorney 1 Okay... Okay so I think you're actually doing a really good job here. You know, asking for parent time.

Ms. Attorney2 Yeah you guys seem on top of it.

Ms. Attorney1 And you're being really specific, that you should have the minimum parent time under that statute and these are your requests.

Ms. Attorney 2 turns to clarify one additional detail:

Ms. Attorney2 And is any of this different to what you guys agreed to in mediation? Girlfriend Just the supervised

Vic =Just to the supervised, that's it. 
Ms. Attorney2 Because you've met the A, B, and C stipulations that she was concerned about?

Vic Pretty much, yeah.

Girlfriend And in verbal conversation she said that if he wants supervised visits he can pay for it. But the thing is he can't even.

Ms. Attorney1 It's expensive.

At this point in the conversation, both the Girlfriend and the Client Vic turn to the lawyers with questions that are a slight expansion of the questions posed on the intake form.

Girlfriend Yeah It's expensive. So if it's like she can't really prove a reason why they need supervised visits, why does that need to be enforced?

Vic So basically I need to know, do I need to hire an attorney for? Because like I go back on the $10^{\text {th }}$.

This is the end of the "interview" portion of the consultation and the beginning of the "counseling" part at 5:28 in the interview.

D. Dismissing the Protective Order Against Polly

In the fourth case, the client's form provides confusing information.

What happened? Briefly describe what has happened that brings you to the clinic:

The Women's Resource Center (@ USU) referred me after their Director (Allison Bona) recommended me after knowing my history as victim - housed at YWCA.

How can we help? Briefly describe what questions you have and/or the help you think you want.

Need to get a "Protective Order" dropped and have my Employee "work hours" subpoenaed verifying he lied to receive it as well as getting acquaintance to testify I'd violated it, thus committing perjury. I'd been beat-up by friends of my Ex on the day arranged for him to finally let me see my kids (after 3 years)....

The answer to the "what happened ... that brings you to the clinic" question, referencing who referred the client to the Clinic, demonstrates a very concrete understanding of the question and may suggest mental health or cognitive issues. The answer to the "how can we help" question identifies getting a "Protective Order dropped" although the "kind of legal issue" checked was "custody" and "guardianship of a child," not "domestic violence" or "changing an order." The "how can we help" question is further followed by a confusing series of goals and a written narrative about having been beaten up. In both her narrative and her identification of the referral source the client reveals herself as a victim of domestic violence. 
Perhaps the interviewing attorney did not read the form; or perhaps he read the form and concluded that it was not helpful in understanding the client's matter. In either case, this attorney asks an open question, interrupts the answer with a clarifying question, and ultimately listens to the narrative the client insists upon telling.

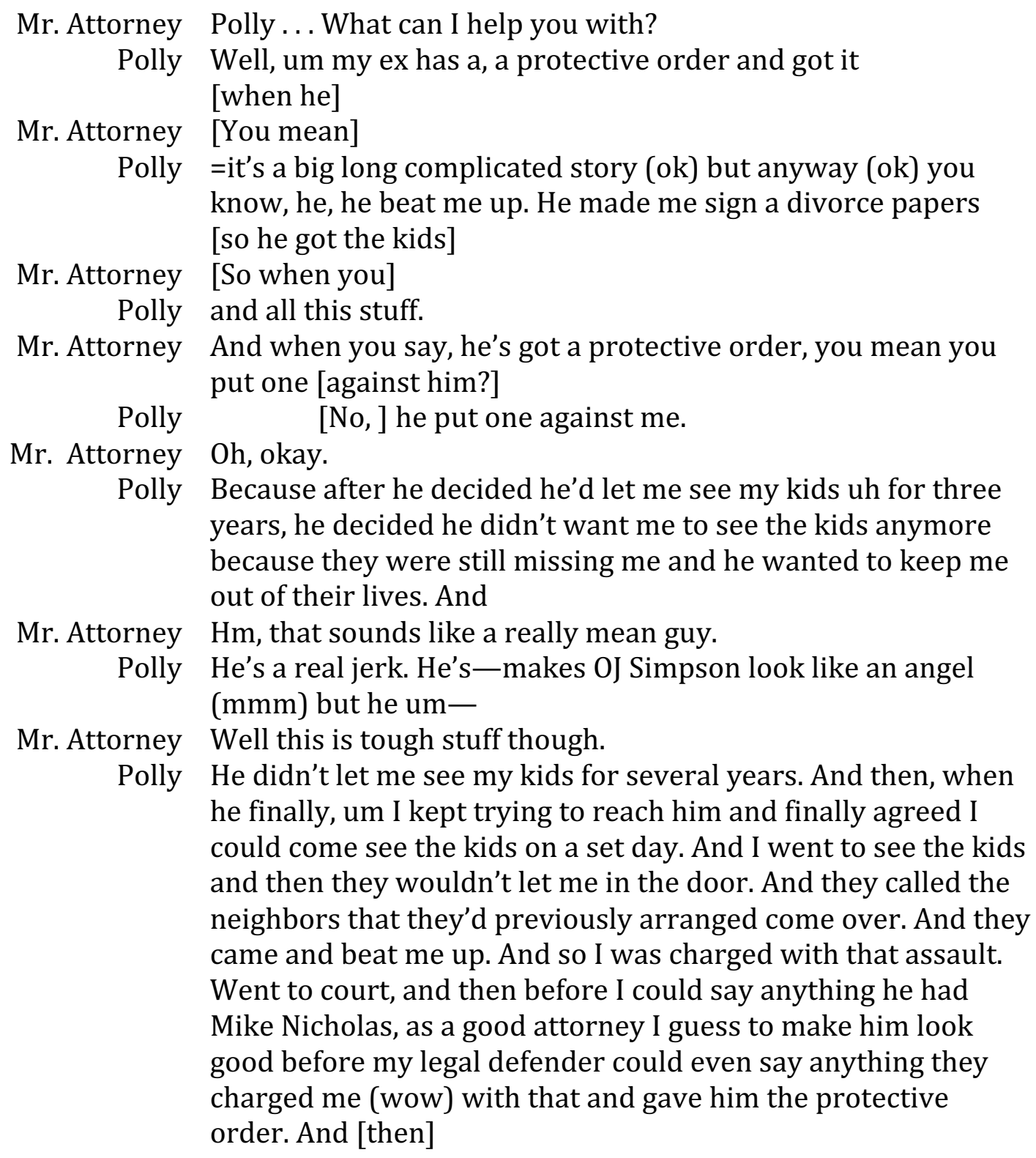

While the client attempts to give a narrative (that seems to deal with the issuance of the protective order), the attorney interrupts to ask narrow questions to determine the procedural posture of the case. During the client's narrative the attorney makes empathic statements ("that sounds like a really mean guy" and "this is tough stuff" and "wow.") Again the attorney interrupts with narrow questioning to diagnose the sort of "protective order" involved and the action that could be taken. 
Mr. Attorney [So] does he have a criminal protective order against you or what they call a civil protective order, the one by a commissioner or?

Polly Yeah it was by a commissioner.

Mr. Attorney Do you know which one?

Polly I think it was Thomas

Mr. Attorney Okay, so yeah, that's a civil protective order, then okay. And how long ago was that?

Polly It was in .. it was uh

Mr. Attorney =The magic number I'm looking for is two years.

Polly I think it was 2011.

Once the attorney ascertains (by getting the name of the person who issued the order) that it is a civil protective order and when it was issued, the attorney begins to provide advice. The attorney addresses the goal set out on the Intake Form's of "need to get a Protective Order dropped":

Mr. Attorney Okay, if it's over two years. You can move to dismiss it. Polly Yeah, so I did file through the court and I do have a date.

At the point the attorney tells the client what she can do (move to dismiss the protective order) the client provides additional crucial information - she has already filed and has a court date! At this point the attorney begins to access the court's docket through his cell phone, to discover more accurately the status of the case.

Mr. Attorney Let me see if I can look that docket up for you. Do you have a case number or let's just look by your name.

Polly Yeah I don't have the case number with me.

Mr. Attorney That's fine, we'll take a look.

Polly The court date is next month.

Mr. Attorney Okay. So are you asking for some advice about what it's going to take to get it dismissed and things?

Polly Yeah.

2:30 Mr. Attorney Okay.

At that point, 2:30 into the interview, the Attorney and client reach an agreement as to the purpose of the consultation and the attorney begins counseling the client.

However, the attorney also continues to consult the docket pertaining to the client's case, and during pauses for this, the client continues the narrative that she wants to convey. 


\section{E. Analysis of the Interviewing Segments}

\section{Presentation of Self}

In many attorney-client conversations, opening exchanges are meaningful, perhaps conveying something about the client as a person or the client's attitude toward the problem. ${ }^{33}$ Sometimes these opening revelations occur during the introduction or "ice breaking," which interviewers are enjoined not to miss. Other times they are provided in response to an open question inviting a client narrative. In this Clinic we must also consider the Intake Form as the client's first opportunity to share meaningful information about himself.

Sociologist Erving Goffman proposes that in all interactions with others, the person is playing a role or presenting himself in the way he wishes to be seen. ${ }^{34}$ "Thus, when the individual presents himself before others, his performance will tend to incorporate and exemplify the officially accredited values of the society, more so, in fact, than does his behavior as a whole."35

In the case where clients first complete a form describing "what happened" and their goals ("how can we help?"), this initial presentation of self is accomplished through this written form. It is interesting that two of the clients (Diane's Divorce and Polly's Protective Order) included very personal and emotionally charged narratives in this intake form, portraying themselves as victims who have been wronged by their spouses. Where a client has elected to be so personally selfrevealing on the form, it should be incumbent upon the attorney to pay particular heed to the information conveyed in this way. Diane's attorney did not reflect or reference the facts conveyed through the form. Polly's attorney appeared to understand from this written narrative that Polly had strong feelings about her situation.

In Vic's Visitation and Addie's Adoption cases, the clients chose not to share relevant facts about "what happened" but only included their goals (stepparent adoption and visitation) and questions about what they should do on the Intake Forms. These clients chose a more protective, less self-revelatory approach. Attorneys who use intake forms should not be surprised that some clients will decline to present themselves and certain facts about their case in writing prior to an actual meeting.

33 See Gay Gelhorn, Law and Language: An Empirically-Based Model for the Opening Moments of Client Interviews, 4 CLIN. L. REv. 321, 325-26 (1998) and Linda F. Smith, Always Judged - Case Study of an Interview Using Conversation Analysis, 16 Clin. L. REv. 423, 442-43 (2010).

34 Erving Goffman, On Face-Work: An Analysis of Ritual Elements in Social Interaction, 18 PSYCHIATRY: JoURNAL FOR THE STUDY OF INTERPERSONAL PROCESSES 214 (1955) reprinted in INTERACTION RITUAL, 5 (1967).

35 Erving Goffman, The Presentation of Self in Everyday Life, 35 (1959). 
This would be entirely in keeping with Goffman's theories about presenting one's best face.

\section{Problem Identification and Questioning}

In all four cases the attorneys rely upon the client's intake form, the client's paperwork, court records, or narrow questions to learn about the client's situation and goals. The attorneys' approaches to these clients is to find out what information or guidance the clients want or need, and turn to provide them with this advice at the earliest opportunity. The attorneys rarely ask for a narrative, interrupt the narrative the client tries to tell, and never encourage the client to expand on any narrative the client provides. This absence of a narrative is despite the almost universal instruction to begin client interviews with a client-directed narrative. ${ }^{36}$ Instead, in conducting the "interviewing" portion of the consultation, the attorneys prefer narrow or yes/no questions, looking for only so much information as is necessary to provide relevant advice in this brief advice clinic.

Two cases involve clients who want general guidance and advice about legal rights and procedures - one regarding Divorce and the other regarding a Stepparent Adoption. In the Divorce case the client has provided a succinct narrative-like statement on the Intake Form about her current situation (having been abandoned after 20 years of marriage with three children and no support) and her questions (rights in a divorce). The attorney may well have found that sufficient introduction to begin to provide the client with relevant information. In the Stepparent Adoption case the attorney asks a dozen yes/no and narrow questions to ascertain whether termination of parental rights would be a viable claim. In both cases the attorneys continue to inquire about the client's situation as they counsel the client (see below).

The other two cases involve clients who have already filed legal papers, and want confirmation and further direction. Perhaps because of this situation, the interviewing portion of these cases is choppy. The attorneys want to home in on exactly what is pending before the court. The clients, in contrast, want the attorneys to understand the complete context of their cases and often respond with narratives when only yes/no or short answers are called for.

The absence of a narrative imposes greater responsibility on the attorneys to ask all the relevant questions if the clients are to receive the best and most thorough advice. As we shall see below, at least three of these consultations fall short on some topics due to the attorney's failure to obtain all relevant information before offering advice.

${ }^{36}$ See supra note 29. 


\section{Rapport}

In the excerpts above two attorneys provide case-specific encouragement. The Divorce attorney tells her client that "at least you can check one thing off your list that you at least applied for legal aid. 'Cause that's the first thing." She then concludes with the genuine empathic statement: "So I'm sorry that you didn't qualify." In the Visitation case the attorney reviews the documents and comments: "Yeah, this makes sense, you're doing the right thing." Later both attorneys opine that the client is "doing a really good job... on top of it" and identify what has been effective - "asking for parent time ... being really specific, that you should have minimum parent time under the statute." In the Protective Order case after the client accuses her ex of having her beat up and denying her parent-time, the attorney provides empathic comments: "that sounds like a really mean guy" and "well this is tough stuff though."

To a large degree the attorneys may be seeking to establish rapport by promptly giving the client what the attorney believes the client seeks - concrete advice about what to do next in her case.

\section{Companion Involvement}

It is interesting that in all four cases the client has brought a companion to the interview. These individuals include the client's fiancé, girlfriend, sister, and friend. In only one case did the presence of a third party evoke a discussion of confidentiality and attorney-client privilege.

While the attorneys generally speak to the clients and the companions speak much less than the clients or the attorneys, they nevertheless play a significant role in these interviews. In some cases the companion serves an important role in moving the interview forward and posing pointed questions. However, sometimes the companion's involvement may not advance the case in the way the client wishes.

In the Divorce Case it was the sister who interjects with the first question - why didn't she qualify for legal aid - that results in the first mini-counseling sessions.

In the Visitation case the girl friend volunteers that the client has already filed court papers and gotten a hearing date, provides the paper work, and later clarifies that the opposing party missed the first scheduled hearing. She adds that the ex-wife has asked that the father pay for the supervision of his visits and then argues against that: "But the thing is he can't even." The girlfriend also broadens the inquiry to include the reasonableness of supervised visits in the first place: "So if it's like she can't really prove a reason why they need supervised visits, why does that need to be enforced?" The girl friend appears to be largely helpful to Vic by providing information, advocating for Vic and insisting that Vic's questions be addressed. 
In the Stepparent Adoption and the Protective Order Dismissal, the companions do not play an important role, and are involved only later in the counseling portion of the consultation.

\section{COUNSELING}

Texts typically present the structure of a counseling session as one in which the attorney clarifies the client's goals, presents alternative solutions to the client, explains the consequences of each choice, and then helps the client decide upon the best course of action. ${ }^{37}$

This structure is not replicated in these consultations. There is little goal clarification. Although there is some discussion of alternatives, the counseling is not framed as a choice amongst alternative courses of action. Instead most of the counseling is the attorney explaining the law and advising client client what to do and how to do it. Sometimes the counseling becomes driven by client questions rather than by the attorney's analysis.

All four attorneys have conducted the "interviewing" portion of the consultation so as to get to the advice-giving portion as expeditiously as possible.

\section{A. Diane's Divorce}

Counseling begins only 42 seconds into the consultation when the attorney answers the sister's question about not qualifying for Legal Aid and then pivots to other options for obtaining a divorce. The first topic - how to do the divorce pro se on line - becomes confounded with the issue of custody:

Ms. Attorney Okay, so it's called the online court assistance program. And the website is UTcourts-

Sister One word?

37 See Binder supra note 27 at 300 recommends "clarifying clients' objectives; identifying alternative solutions; identifying the likely consequences of each alternative; and helping client decided. ..."; Ellmann supra note 27 at 72 recommends the attorney "clarify ... the client's goals; identify the choices available to the client to achieve the goals ;... predict the most likely outcomes of those choices; identify the consequences of those options ...."Herman supra note 27 at 63 recommends addressing six questions: "factual and legal situation ... objectives or goals. . . options .. pros and cons and likely outcomes of each option; which option should your client choose. . . how will the option ... be implemented?"; Krieger supra note 27 at 239 recommends "identifying the client's goals and developing ... potential solutions" and at 245 analyzing "the advantages, costs, risks, and chances of success of each potential solution...." 
Ms. Attorney Uh huh-dot gov. And it looks like that you'll recognize it up there. And they have the forms available. They have lots of great information. It's kind of information overload, so just take some time and go over that um if you want to do a divorce by yourself. A lot of people do, it's called doing a divorce pro se, which means you're doing a divorce without an attorney. And a lot of people, that's a great fit. Um one of the advantages is that it's very cost effective, um.

Sister $\quad$ Okay what if it's probably not going to be an easy divorce?

Ms. Attorney And that's one of the things you might also want to do, is meet with an attorney. So um there's a lot of attorneys that you can call and ask for a free consultation. You can look in the phone book, um you can call the Utah State Bar, and you can call attorneys randomly and ask them for information, how much their retainers are. Um, depending on the the divorce, retainers can range.

Sister Well there's three kids involved.

Ms. Attorney Okay and and are, they're, they're all under 18?

Diane Yeah.

Ms. Attorney Okay.

[Okayeee]

Sister [So how easy] do you think it would be to do it yourself? With the custody?

Ms. Attorney It, will custody be contested?

Diane Probably.

Ms. Attorney It's going

[to get pretty complicated.]

Sister [Can't say No] to that <chuckling>

Ms. Attorney It's going to be pretty complicated. So I think the first thing is to understand what your rights are and really make an informed decision on whether you want to do it without an attorney or whether you want to do it with an attorney. You should also know that attorneys are occasionally also able to ask for attorneys' fees from the other sides if they're able, in a better financial situation to pay for um, that.

Diane [Yeah that was my question.]

Ms. Attorney [However oftentimes,] they're not awarded, so you would, I don't want to get into the specifics on your case. But just know that that can sometimes happen. It is rare in a lot of cases, especially when there's just not a great deal of money one way or another. But that's something to keep in mind too when you're considering your options. But um, what direction do you want me to go? Do you want me to tell you the basic process of how you would go file and by yourself? Or even if you- 
The Attorney's counseling focuses on process. In this segment she encourages the client to consider the option of proceeding pro se, calling it " a great fit" for a "lot of people" since it is "very cost effective."

The sister raises problems with this approach, first interjecting with a question "what if it's probably not going to be an easy divorce?" - later mentioning that there are "three kids involved" and still later asking how easy would it be to proceed pro $s e$ "with the custody."

The attorney declines to interview to discover what will be difficult about this divorce and why. She asks if custody will be contested and when the client says "probably" she concludes "It's probably going to get pretty complicated." The attorney declines to interview about the merits of the custody case: How old are the children, how long have the parties been separated, who has had custody since the separation, who has been the primary caretaker during the course of the marriage, what arguments would the father make for custody? The attorney should know from the Intake Form that the husband "walked out... has taken no responsibility at all. Only sees the kids when he wants" and failed to pay rent after having promised to do so, leaving the mother and children homeless. These facts do not make for a strong custody case on the father's behalf! Yet the attorney never provides the client with any opinion as to the strength of her custody case or even explains the legal standards for custody.

The attorney does suggest different processes: proceeding pro se, calling private attorneys and finding out how much they will charge, or retaining an attorney with the hope that the other party would be ordered pay the fees. Ironically, the attorney urges the client to "understand what your rights are and really make an informed decision" on whether you want to proceed pro se or hire an attorney, while failing to give her an opinion as to the strength of her case.

The attorney offers to better explain the pro se process, but the sister changes the topic to "child support." During this exchange it is primarily the sister who is directing (and sometimes confusing) the consultation:

Attorney But um, what direction do you want me to go? Do you want me to tell you the basic process of how you would go file and by yourself? Or even if you-

Sister Child support.

Attorney Child support, [okay.]

Sister [Child support.] Does um ORS, you need a court order don't you before they can do anything about child support?

Attorney Um, yes. So basically what um, right now, there's no orders in place okay? So what a lot of people do is they file the petition for divorce, or the compliant for divorce, I believe it's what it's called. And that gets the process going. Okay. But that often takes a long 
Diane

Attorney

Sister

Attorney

Sister

Attorney

Sister

Attorney

Diane

Attorney time to resolve. So especially when there's children, and do you, do you own a home?

No.

Okay, um. If there's children and other issues that need to be dealt with immediately, a lot of people file what's called a motion for temporary relief. Which is saying, okay, we filed the pet- overall big petition, right? But until we get all the major things resolved, we need guidelines to follow while we're getting this divorce resolved. And that's if it's going to be contested. And so you would do a motion for temporary orders where you would ask for child support. And you would ask to define to custody. So in your case, if you were trying to get sole custody, doing not just on a permanent basis, but on a temporary basis, you would need an order, and you would ask for that. Otherwise there's no orders guiding, for example, custody. Um, there's [just no nothing.]

['Cause technically] right now you don't have custody, and neither does he.

Well you, you both do <chuckles>.

[That's how]

[He could come], he could file it, if he files it before you do, he could [have custody.]

[Not necessarily] who files it, because just because you file it does not mean that there's an order. I, I kind of look at divorce petitions as like wish lists. This is what you're asking for, this is your wish list, but no one has [signed off on it.] [I'm not saying] it's not necessarily going to happen, but. $<$ chuckles $>$

So that's more [if it's contested.] [Well see he left me] and the kids. (Okay) He walked right out on us. (Okay) And he hasn't supported us at all since he left. He hasn't given them money for food, nothing.

Okay. So if you file a divorce, you file for divorce, I would recommend filing for a motion for temporary orders right away, to get some orders in place.

Rather than explaining the standards for child support, or helping this client calculate the amount of child support she should receive, the attorney focuses upon the process for obtaining child support - filing a motion for temporary orders. The focus is probably useful, as the client is not receiving any support from her husband, but is not sufficient. However, the process is complicated, as the client must first file the divorce petition before filing a motion for temporary orders. The attorney tries to explain this referring to the "overall big petition" and the need for interim 
"guidelines." Recalling the client's desire for custody, the attorney explains that the client would also ask for temporary custody in the motion.

Once the topic of "custody" is raised, there are seven turns, each of which is interrupted by the next speaker, seeking to control the floor or to correct another's analysis. The sister interjects her advice that "technically right now you don't have custody and neither does he" which the attorney counters with the technically correct answer that "well, you you both do." This leads the sister to warn that if the husband files first "he could have custody." Here the attorney corrects the sister again, explaining that it isn't necessarily who files first and filing alone won't result in an order, but she does not explain that both parties would be notified of the hearing for temporary orders. Instead she goes on to describe the complaint as the client's "wish list." At this point the sister interjects that "it's not necessarily going to happen," perhaps defending her assertion that the husband might file for custody first. The attorney begins to respond to the sister. At this point the client finally speaks up, interrupting the attorney, and provides her short narrative, asserting the facts that she feels give her case merit (and which she had included on the Intake Form) - the husband abandoned her and the children and he hasn't support them since he left. (See italics above.) The attorney turns to give attention to the client and her strong assertions, saying "okay" after each utterance.

Unfortunately, the client's strong assertion doesn't evoke an empathic reflection or further interviewing about the custody issue or assurance that the client is likely to be awarded custody and child support. In response the attorney urges the client to seek temporary orders "right away" to which the client responds "okay." Here again, the attorney is focusing on the process that needs to be followed without providing any substantive advice or assurance to the client that her theory of the case has merit and she will likely prevail.

However, the client explains (not excerpted) that she has had difficulty completing the on-line forms and the attorney directs her to the Legal Aid office that will help people use the On-Line Court Assistance Program. Thereafter the attorney empathizes with the client about all the paperwork that is required and, although people do this themselves all the time, it takes a lot of patience.

The next topic (not excerpted) is selected by the client - getting the husband taken off her health insurance, as covering him is very expensive and he has his own insurance. She explains that her employer needs a "legal separation or divorce paper" to allow her to do this. Here the attorney first suggests that the temporary motion provide for the husband to reimburse her for these costs, but then suggests that she ask that the temporary order permit him to be removed from her insurance. The attorney concludes: "But again I've never dealt with that issue, but that's that's one way that might be a possibility. It's worth looking into, but I'm not going to tell you that's going to work." The attorney goes further and describes the ultimate arrangements the parties may have on health insurance, explaining the option of 
having only one party insure the children and the legal standard that the other party would reimburse that party for half of those costs.

At the conclusion of the insurance discussion, the attorney again asks what more the client wants to learn: "So we have a little more time to go over more of the process or whatever information that you would like." This leads to the following exchange:
Diane
Yeah, just like where I would start.
Sister Do you do divorces?
Ms. Attorney
Diane I don't do any type of, I have experience in it. But, I don't do any referrals from here at all. So I'm not even going to tell you [my last name <chuckling $>$ ].
Sister [<chuckling $>$ No it is just]
Attorney How many divorces have you done?
Sister Attorney Quite a few. Quite a few. [That's all I was wondering.] [<chuckling >Oh, okay. Okay.] Um, so, I can tell you just the process. For example, once you file, you if you serve the other person, you can do that service through a constable. Or um actually taking it to him and having him served?

The attorney understands the sister's question to be an inquiry about this client retaining her. The attorney's response is a face-threatening statement that she doesn't take referrals from the Clinic and will not even give her last name. The attorney does not explain that due to the bar's prohibition on personal solicitation, she has chosen not to accept paying cases from the Family Law Clinic. ${ }^{38}$ This could leave the client and her sister feeling rejected without any rationale. The Sister deals with the attorney's rejection by a follow-up question regarding how many divorces the attorney has done, as if suggesting she was questioning the attorney's competence rather than looking to retain her. The attorney is inexact in her answer and the Sister does not follow up with any challenge, commenting that she was just wondering. Fortunately, this uncomfortable exchange is concluded when the attorney reiterates her offer to further explain the process to the client.

The consultation continues with the client's sister continuing to name new topics and the attorney responding to them. The next topics (in order) are the time it takes to have the divorce finalized and the divorce education class. In explaining about the divorce education class the attorney returns to the topic of temporary orders, recommending that the client seek temporary order when she files her complaint. In explaining what could be addressed in the motion for temporary orders the attorney

${ }^{38}$ Rule 7.3 of the Utah Rules of Professional Conduct prohibits in-person solicitation of clients "when a significant motive for he lawyer's doing is the lawyer's pecuniary gain ...." See also Rule 7.3, Model Rules of Professional Conduct 
is reminded that the client is currently homeless, and takes that cue to explore the possibility of alimony.

Ms. Attorney Okay. So in the temporary orders, you want to do child support, the health care issues, um and you're not, you don't own a home, so you're renting. [Are you both on the lease]?

Diane [No not even that either] cause we got kicked out of the apartment cause he quit paying that.

Ms. Attorney So are you staying with the family?

Diane Yeah.

Ms. Attorney Okay. Um, and do you have a big difference in your income?

Diane Yes, he makes like \$27 an hour I make nine.

Ms. Attorney Okay, so and you have a long-term marriage. So um they don't give alimony quite as much. They usually, if they do, it's more on a temporary basis. However where there's longer term marriages, where there's a big discrepancy in income, your chances of getting alimony are much higher. Now it's very, very important to fill out what's called the financial declaration. Okay? And I believe that's available online too. Now if you ask for alimony, it's um, you have to fill out the financial declaration form. And you can ask for alimony on your petition and that's usually the difference-this is kind of hard to think about here. But the difference of what you your monthly expenses and your net income.

Diane Oh there's a big difference on that one <chuckling>.

Sister

Ms. Attorney So between what she brings in and what he?

Not him. It's not about him right now. It's about when you're asking for alimony it's what you need every month to survive.

Diane It's different from the kids' though, right?

Ms. Attorney Mnn you'll need to add in the child support. When you're kind of calculating it, it doesn't need to be exact. But.

Sister In the alimony?

Attorney

Umhm. Let me do a quick—okay let's say that you, your living expenses for you and the children are $\$ 3,000$. OK. And you're going to have the kids, so that's part of it, right? So it's $\$ 3,000$. And right now, when you fill out the financial declaration you would need to put what you're paying for housing, or, and that's important when you do the worksheet, and all of your expenses, all of your gas, your electricity, the kids activities, groceries, all of that. So let's say that that turns out to be $\$ 3,000$. And you gross $\$ 2,000$, but with all of your-I'm just making it up here. And then you have all of these taxes and everything else, so you bring home let's say $\$ 1500$ after everything. So you have a $\$ 1500$ gap, right? Let's say he makes, we 


$\begin{array}{ll}\begin{array}{l}\text { Diane } \\ \text { Ms. Attorney }\end{array} & \begin{array}{l}\text { ask for. } \\ \text { Okay, I get it. } \\ \text { So I'm not saying you're } \\ \text { [going to get it.] }\end{array} \\ \begin{array}{l}\text { Ms. Attorney } \\ \text { Diane }\end{array} & \text { [I haven't have a clue] at that. } \\ \text { Ms. Attorney [not going] to say you're getting it. } & \quad \text { [Oh no.] } \\ & \begin{array}{l}\text { But you might as well ask for it. But be aware that puts a more } \\ \text { burden on you to fill out the financial declaration form, to be really } \\ \text { careful and honest about that. Okay? }\end{array} \\ \text { Diane } & \begin{array}{l}\text { Very detailed [and Sister inaudible] } \\ \text { Attorney }\end{array} \\ & \begin{array}{l}\text { To provide your income verification. And you're going to need to } \\ \text { file your W-2's from last year as well as your to-date paycheck } \\ \text { stubs. That's really important. The commissioners get really get } \\ \text { annoyed if you don't do that. . And be sure, right now to any } \\ \text { documents that you have, I would make sure that they're in a safe } \\ \text { place, financial documents. I don't know how many times you hear } \\ \text { people say, well I put it in a safe but he stole the safe! So you keep, } \\ \text { be smart about that. }\end{array}\end{array}$

don't, we're not really focusing on him, but let's say he makes, his gross is $\$ 4,000$. And we'll say, you know what, he makes that amount, he has the ability to make up that difference. And if your child support, let's say is $\$ 600$ when you're thinking about it, you don't need to justify it there, if you're really credibly thinking about it, you're like "I'm going to get based on this specific income, I'm going to get $\$ 600$ in child support, so I need $\$ 900$." That's what you ask for.

In the course of explaining what should be included in the motion for temporary orders, the attorney again forgets that the client is homeless and asks who is on the client's lease, only to have the client again recount the facts conveyed on the Intake Form - the client "got kicked out of the apartment" because the husband "quit paying rent." (See italics.)

The attorney next asks about the parties' respective incomes. Once the attorney learns that the husband earns about three times as much as the client earns, she reaches out from beyond what the client was clearly inquiring about to advise the client to request alimony. Although when discussing custody the attorney declined to gather enough information to provide personalized counseling, here the attorney independently identifies an issue and recommends the client pursue it based on the interview question and answer.

The attorney explains how the need for alimony is assessed and provides a hypothetical mathematical calculation to do so. While the dialogue about the 
calculation may seem difficult to follow, it is likely that the attorney and client were doing the calculations on a sheet of paper to illustrate them concretely

The final topic is also suggested by the Sister: how do they divide up the bills. This leads the attorney to further advise about dealing with debts, payments on debts, and possession of automobiles in the motion for temporary orders.

Over a 33-minute consultation the attorney discusses relevant topics including child support, getting temporary orders, child custody, removing the husband from the client's health insurance, the process of filing and serving the husband, the time involved, the divorce education class, possession of the parties' cars, the possibility of alimony, and responsibility for the parties' debts. Many of these topics are initiated by the sister rather than by the client. At various points the attorney moves from the substantive law topic (e.g. child support) to again discuss processes (filing the case and filing temporary motions). On most of the topics the attorney does no or limited questioning before providing the information that she deems relevant. Much of the attorney's "counseling" is generic information as opposed to targeted advice for this particular client in her particular situation.

One challenge in this consultation is the extensive involvement of the client's sister. The sister continues to select topics for the attorney to address and to propose conclusions for the client. One can question whether the sister is primarily helping Diane or using the legal interview to convince Diane of what the sister thinks she should do.

Another difficulty with this 33-minute consultation was its scope. So many topics were covered, that it is unclear what the client will be able to remember and act upon. While the attorney attempted to focus on the most pressing issue (getting a petition filed and temporary orders in place), the sister's and client's frequent questions about more fine-grained issues (health insurance, debts) makes it difficult to know how the attorney should have simplified the consultation. While the court's website contains a plethora of information that the attorney recommends and the attorney refers the client to the Legal Aid office for help with the OCAP forms, this client might have benefited from a written outline of next steps and summary of this advice.

\section{B. Dismissing the Protective Order Against Polly}

As set forth above, the attorney begins providing this client with relevant information - she can move to have the protective order dismissed after two years only two minutes into the conference. Once the client informs the attorney that she has already filed such a motion, they both agree she wants "some advice about what it's going to take to get it dismissed." The attorney provides the following advice:

Mr. Attorney Okay. So are you asking for some advice about what it's going to take to get it dismissed and things? 


\begin{tabular}{|c|c|}
\hline olly & eah. \\
\hline Mr. Attorney & Okay. \\
\hline Polly & $\begin{array}{l}\text { I want to make sure I defend myself right, because he } \\
\text { [plus the fact] }\end{array}$ \\
\hline Mr. Attorney & $\begin{array}{l}\text { [Well first of all] you're not really defending, because you're } \\
\text { the one moving to get it dismissed. }\end{array}$ \\
\hline Polly & Yeah? \\
\hline Mr. Attorney & $\begin{array}{l}\text { But the main issue here is that it's no longer needed, is your } \\
\text { main argument. }\end{array}$ \\
\hline Polly & Yeah. \\
\hline Mr. Attorney & $\begin{array}{l}\text { To put it in layman's terms, the simplest argument is, the } \\
\text { protective order isn't needed. If you get into why it's fake and } \\
\text { why it's bad and all these other things, those are great, but you } \\
\text { know he's going to come } \\
\text { [back to that] }\end{array}$ \\
\hline Polly & $\begin{array}{l}\text { [that won't] yeah, it won't be the time to bring up those points } \\
\text { you think that }\end{array}$ \\
\hline Mr. Attorney & $\begin{array}{l}\text { It, it could, I mean they're not bad points, they're good points } \\
\text { and you might want to use them. } \\
\text { [It's about picking your battles.] }\end{array}$ \\
\hline Polly & [In defense if I need to.] \\
\hline Mr. Attorney & $\begin{array}{l}\text { Well it's about picking your battles. And if you attack that, he's } \\
\text { probably going to come back and say alleged mental health } \\
\text { issues, alleged all these things. }\end{array}$ \\
\hline Polly & Yeah. \\
\hline Mr. Attorney & $\begin{array}{l}\text { If you don't fight with the main issue, which is when you tell } \\
\text { the judge, which is what I would focus on if I was your } \\
\text { attorney, and say it's not needed .. because if it's not needed it } \\
\text { gets dismissed. Let's see if I can find it for you. It's under this } \\
\text { name? }\end{array}$ \\
\hline
\end{tabular}

Here the attorney is advising her what she should argue (the Protective Order is no longer needed) without doing an interview to see if such an argument is merited by the facts. He has obviously read the Intake Form as he also advises her NOT to focus upon the argument that the Protective Order was based on perjury, an approach that would have no chance for success.

However he leaves the choice up to her while suggesting that she needs to "pick her battles" and predicting that challenging the legitimacy of the Order in the first instance will invite the opposing party to allege "mental health issues ... all these things." After reiterating the argument that "it's not needed" the attorney turns to look up the case on his cell phone.

As the attorney searches the docket, noting that it appears there are seven separate cases, the client continues to provide a narrative. She provides further detail about the incident she has already described, detailing her interaction with the police who 
arrested her, and going on to discuss another dispute with the ex-spouse. Then the client volunteers as follows:

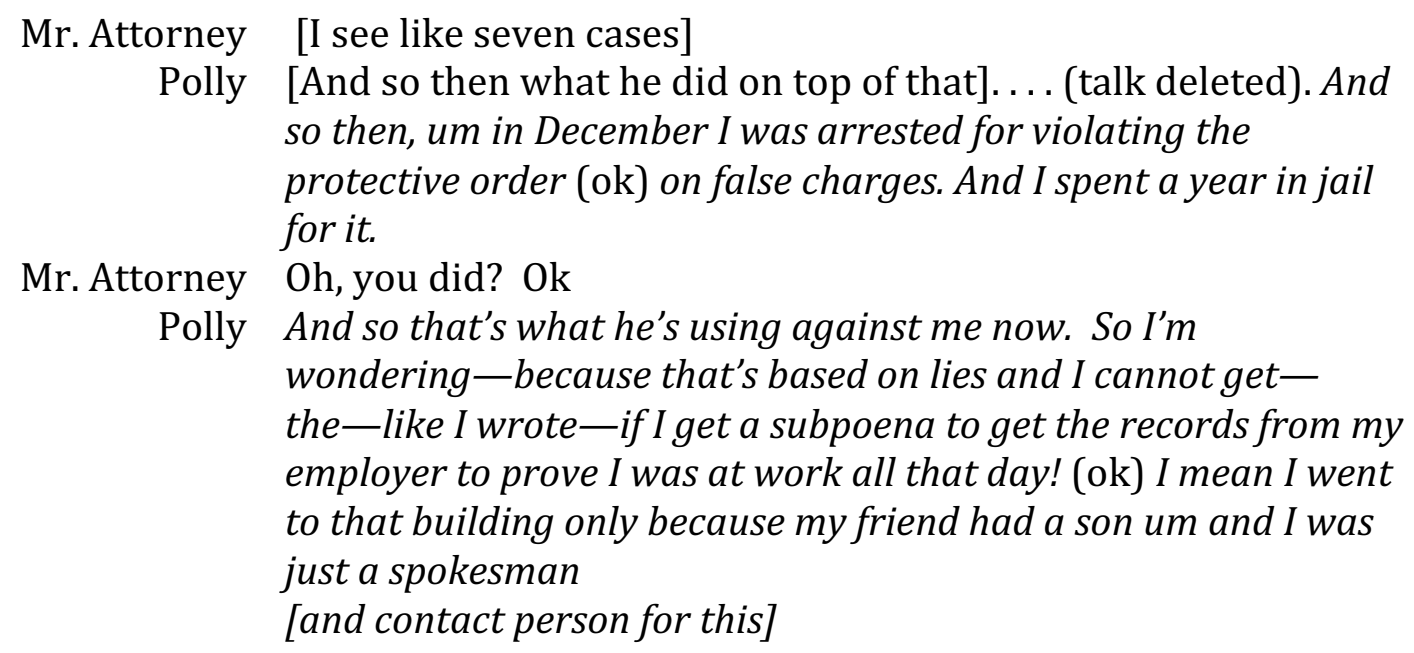

Although the Attorney has already advised Polly to argue that the Protective Order "is not needed" he now discovers that she has been arrested and convicted for violating the Protective Order, spending a year in jail for that violation, facts that make this argument seem very weak if not foolish! This exchange highlights the importance of interviewing before counseling.

It is noteworthy that the client has chosen to reveal these negative facts about her situation without any prompting and as part of the narrative she insists upon giving. This client's insistence upon presenting relevant, even negative, facts is consistent with philosopher Grice's maxims included in the cooperative principles, that conversation partners say as much as required and say what is true and relevant. ${ }^{39}$ Similarly, these disclosures were worked "into the conversation" so that "the facethreatening implications should be lessened." 40 This is an additional reason to allow the client to give a narrative - so that she can share negative facts in the least facethreatening way.

The client concludes her narrative with a "coda" - shifting "to present timereference to restate the meaning or moral of the story" in explaining this is what her ex-husband is using against her, and an "evaluation" - commenting "on the action

\footnotetext{
39 See H.P. Grice, Logic and Conversation, in Syntax And Semantics Vol. 3 at 45 (P. Cole \& J. Morgan, eds., Academic Press, 1975). See also Smith, Client-Lawyer Talk: Lessons from Other Disciplines, supra note 22 at 530-534 discussing clients' motivation to provide relevant information irrespective of question form 40 Thomas Holtgraves, The Language of Self-Disclosure, in HANDBOoK of LANGUAGE \& Soc. Psychol. (Howard Giles \& W. Peter Robinson, eds.) 191 (1990).
} 
from outside the story"41 - in explaining that the conviction for violating the Protective Order is one reason she thinks it may be useful to attack the validity of the Protective Order in her quest to have it dismissed. What may have seemed like a client rambling on was actually a complex narrative the client had a reason to tell.

The attorney knows that such an argument would have no merit in seeking to dismiss the Protective Order, so he addresses the only theoretically possible approach, attacking the conviction itself.

$\begin{array}{cl}\text { Mr. Attorney } & \text { [Well here's a], here's a problem. You're crossing over the } \\ \text { criminal domain by trying to fix things that have happened } \\ \text { criminally. Um, unfortunately you know, once you're convicted, } \\ \text { you're convicted. It's very hard to get } \\ \text { [those set aside.] }\end{array}$

It appears that the scope of the client's goals have now been widened to include vacating her criminal conviction and charging the witnesses against her with perjury. This counseling, while technically accurate and respecting the client's right to choose her course of action, seems to suggest a wild goose chase rather than a reasonable alternative solution to the client's problem.

\footnotetext{
${ }^{41}$ Deborah Cameron, Working with Spoken Discourse, 152-53(Sage, 2001). Cameron identifies the five sections of the prototypical spoken narrative: abstract, orientation, complicating action, coda and evaluation.
} 
The attorney returns to his cell phone, seeing "several cohabitant abuse actions" and the client returns to a disjointed narrative about abuse she has suffered at the hands of her ex-spouse. Ultimately the attorney discovers that the minute entries on the docket say something "was returned unserved." There follow multiple exchanges in which the attorney advises Polly that she should make sure that the ex-spouse is served with her motion.

This exchange is an example of the brief advice clinic focusing, of necessity, on HOW to do something, rather than legal analysis or choices between options. This sort of information about how to accomplish service could very well be relayed by nonlawyer personnel. However, the lawyer's access to the court's docket was crucial in helping the client prepare for the hearing.

After the attorney volunteers to look into the other cases between Polly and her exspouse, Polly again launches into a narrative of having been abused by her ex. This time she concludes with complaints about the way the divorce was resolved. And Mr. Attorney turns to advice about that issue.

Polly .... [dialogue deleted] ... I didn't have an attorney, I'm just sitting here struggling to going to school, trying to support myself because he beat me up and made me sign his divorce decree. He got custody, the house, the kids, he doesn't pay any alimony or child support. So I was penniless, trying to support myself and get on track here [and so].

Mr. Attorney [You may] want to consider motion to modify on that. Um you

Polly Can I still do that?

Mr. Attorney You can always move to modify the divorce.

Polly Oh, I didn't know that.

Mr. Attorney I'm going to go show you the forms for that. Sounds like you have what I call a trunk load of legal problems. (Yeah.) One is you've got a problem with the divorce being unfair, you can move to modify that to fix it. That is a long, difficult process. But I can give you the forms to get started. [More importantly]

Polly [Well I didn't know that I can] if he's the one that divorced me. Mr. Attorney Yes you can, yes you can. You have to show a substantial change in the circumstances. (OK) Something that wasn't contemplated at the time of the divorce. That's something we can do. (Okay) Other than that, all of the cohabitant abuse that I was looking up, I was looking at one of the six. And a lot of them look like they were dismissed. The one that I have here is the '06 one, um that's the one that it looks like you have your hearing on. The important thing to realize is that you need to show that the protective order doesn't need to exist anymore. That's the main issue. 
Here the attorney picks up on the client's frustration with the outcome of the divorce, and advises her that she could move to modify the divorce. Again, he does not interview her to determine whether there are grounds for a modification. However, he does provide her with the relevant legal standard for a modification: a substantial change in circumstances. In this exchange the attorney does both too much and too little. He recognizes and validates her strong feelings about the unfairness of the divorce by telling her that divorces can be modified and giving her the legal standard. But he fails to inquire about her circumstances so as to analyze whether there would be any likelihood of success in such a case. She may feel good about this consultation, but she is ill prepared to do anything as a result.

At this point a male friend of the client arrives and begins to participate in the consultation. The client catches him up on what she has been advised. Then the attorney looks up the statute that deals with dismissing protective orders and reads it to the client and her friend.

Neither the attorney nor Polly discusses this standard or explores what facts may exist to meet it. Rather than apply this standard to the facts of her case, Polly and her friend turn to discuss abuse that happened 20 years ago and her ex's violation of a prior protective order. The attorney again advises that prosecution for such a violation is in the control of the DA. The attorney returns to the statute he has just read on his phone, and provides them with the proper citation and explains that it can be found in the court's law library or on-line.

Next the client complains that Legal Aid would not help her because her ex was once represented by Legal Aid, prompting the attorney to explain conflicts of interest and to confirm that Legal Aid would not be allowed to represent her because "that's Utah's bar rule." He does refer her to Utah Legal Services, a second agency that often accepts clients when Legal Aid has conflicts of interest. Polly updates her friend on the advice about completing service for the up-coming hearing and $\mathrm{Mr}$. Attorney reiterates his advice on that point to both the client and her companion. As the attorney is providing his final review the friend raises a new topic, the custody of the client's children:

Polly Okay.

Male Friend What if the children, because they're over 14 and [inaudible]?

Mr. Attorney [Want to come and live with her?]

Male Friend Don't want to.

Mr. Attorney Don't want to come to live with her? Any child over the age of twelve

Polly [Can pick who they want huh?]

Mr. Attorney [Not really.] There's, there's a factoring system. Custody's got like nine factors the judges look at to determine where custody should go. That would be in your motion to modify. Any child 
over twelve, more and more weight is given to their determination. It's not the only determination, but more weight is given. A child over the age of 16 , very, very, very much weight is given to it. So if you have a 17-year-old saying he doesn't want to live with mom, or he doesn't want to live with mom, it's going to take a mountain of evidence to show that he should=

Polly He hasn't lived with me for ten years so, and he hasn't seen me for seven, so it's like, how can you prove the point that he violated my visitation rights which has affected, you know, had quite an impact on the kids, so?

Mr. Attorney You're right, it's difficult. But, sometimes with a 17-year-old, because as soon as he's 18 he gets to make his own call anyway-sometimes with a 17-year-old, your motion is less important to actually get custody, because by the time you got it it would be too late $(\mathrm{mhm})$, and more important to let him know that you're here $(\mathrm{mhm})$ and that you want to have that connection.

Polly Yeah.

Mr. Attorney So it's not, it's not in vain. Okay, so those are really your main issues. Let me take you down to show you those motions to modify.

Polly Okay.

Here the attorney explains that children's preferences are not the determining factor in deciding custody, but are given more weight as the children get older. The client clarifies that the children haven't seen her in many years and then asserts that her ex has violated her visitation rights and had "quite an impact on the kids." The attorney appears to understand that it is the client who has suffered "quite an impact” from having been excluded from her children's lives for so long. He concludes that her motion for custody is "less important to actually get custody .. .and more important to let him [your son] know that you want to have that connection." For this reason, the attorney concludes that "it's not in vain" and proposes to show her the form motions to modify custody.

The counseling session was quite far-ranging, focusing upon dismissing a protective order and serving notice of the hearing, but also touching upon vacating criminal convictions, prosecuting witnesses for perjury, prosecuting the ex for violation of a prior protective order, conflicts of interest preventing Legal Aid from taking the case, and pursuing a modification of the divorce decree. The attorney generally failed to interview the client to see if she had grounds for what she wished to do and to advise her from that perspective. Indeed, the fact that the client had violated the protective order and served a substantial sentence for that violation would argue strongly against her succeeding in getting the protective order dismissed. 
The counseling session also focused on how to carry out the various processes, not why or whether to proceed. Because the attorney did not explore the client's goals -why the client wished to have the protective order dismissed -- the attorney was not able to advise whether the dismissal would provide the benefit sought. The context of the consultation suggests that the client may felt that the protective order (prohibiting her from communicating with her ex or going to his home) has been the reason she has been kept her out of her children's lives. Perhaps she thought that the first step in being able to see her children was to dismiss the protective order that prohibited her from communicating with their father and going to their home. If so, the attorney's final suggestion of a divorce modification did speak to the client's emotional needs. He concluded by telling her that bringing a modification case would not be "in vain" because it would communicate to her child that she wanted to have a connection.

The strengths of this consultation were the attorney's empathy for the client who presented a "truck load" of problems and appeared to have a near hopeless case. The attorney's approach of providing legal standards rather than personalized advice after a thorough interview may have avoided a discussion of how difficult it will be to achieve the client's goals. Similarly, while the attorney's willingness to address the full range of issues the client raised (e.g. dealing with alleged perjury and unfair convictions) showed respect for this client, the attorney avoided candidly predicting that these solutions were pipe dreams.

\section{Addie's Stepparent Adoption}

During two minutes and forty seconds of interviewing, this attorney has learned that the biological father acknowledged paternity at birth and was ordered to pay child support, but has never paid any support, has now has been in jail for a year and has seen the six-year-old child one to three times in her life. With this factual basis the attorney begins to provide legal advice to the client but also continues to interview, explaining the relevance of the questions and the legal standard for parental termination:

Ms. Attorney Okay, well the reason that is important is I know you checked termination parental rights. One of the things the courts look at is, is there a parental bond between the parent and the child. So like my answers to later questions would be different if you said he had a regular visitation schedule, he bought her clothes, he did all this other stuff versus he's seen her once or twice. Okay, so you are interested in terminating his parental rights.

Addie Right.

Ms. Attorney Okay. That usually goes through juvenile court.

Addie Okay. 
Ms. Attorney Okay. And, um, there are several factors involved in that. Probably one of the most important in that is, is there a parent-child relationship. So the court will be most interested in what happened before he went to jail, okay? Now other things that the court looks at, for example, did he buy Jasmine presents for her birthday and Christmas?

Addie Okay.

Ms. Attorney I, I mean these are specific questions. So after you left the hospital, he never paid child support? (Inaudible) Don't make a big deal out of that because, the financial part is not the reason to terminate parental rights. If anything it would be reason to keep him on it, so don't make a big deal about that. (Okay)But he never bought her birthday presents or Christmas presents, but did he contribute to her clothing or anything like that?

Addie Hm-m.

Ms. Attorney Okay, he saw her maybe once or twice? And when he saw her, was it because you asked him to or did he do this on his own?

Addie He did it on his own.

Ms. Attorney And how long did he have Jasmine at the time?

Addie Well I was there the whole time it was probably about an hour.

Ms. Attorney All right. That is important too. So he saw her once or twice, for about an hour and you were there. Okay [M-hm] Those will all become important. It is called a Petition to Terminate Parental Rights. It'll go through, it would go through the juvenile court system.

Addie Okay

The lawyer begins to counsel by describing a general legal standard (whether "there is a parental bond") and then interviews further about presents and brief visits. She explains that these facts will be important and the client comes away with the legal standard and some idea of the evidence she needs to present to the court for the parental termination case.

At this point, the attorney returns to the client's Intake Form to cover other questions the client has identified. These include custody, name change, and stepparent adoption. Each topic results in a short interview and personalized advice about what to do in light of the applicable law. The attorney and client return to the parental termination/step-parent adoption to further discuss strategy.

Regarding custody, the dialogue is as follows:

Ms. Attorney Uh, now, you are a single parent, custody has never been established, so it is assumed that you have custody?

Addie Right.

Ms. Attorney So, you checked custody, what were your questions on that? 
Addie Well I wasn't sure if I needed to like gain custody and then terminate his rights or like, how to go, what I needed to do?

Ms. Attorney I would say go- what you need to do is file to terminate his parental rights.

Addie Okay

Given that the client's goals are to terminate parental rights, and given that she has a strong case and the opposing party is incarcerated, this attorney gives the client directive, strategic advice to simply pursue a parental termination case rather than begin a custody case. This is clearly the correct strategy in this case. It is also a good example of where an attorney may tell the client what to do rather than provide the client with lengthy explanations of options.

The next topic is adoption, which the attorney also initiates, relying on the intake forms.

Ms. Attorney Um, now you have also checked adoption?

Addie 'Cause he wants to adopt her so he can change her last name.

Ms. Attorney Okay well that's called a stepparent adoption, and y'all would have to be married for a while before you could do that.

Addie Right

Ms. Attorney And, you could even do that without terminating parental rights. .to What's the father's name?

Addie Chuck

Ms. Attorney Would Chuck agree to to let you adopt Jasmine?

Addie No he wouldn't.

Ms. Attorney Have you raised that issue with him?

Addie Uh-huh.

Ms. Attorney Okay, 'cause that, I don't believe people should spend money on lawyers if they don't have to.

Addie Right

Ms. Attorney If Chuck would agree to it, then you wouldn't have to go through all these termination of parental rights... Um, this is not exactly a legal question, but it becomes a legal question. Does Chuck have money?

Addie No.

Ms. Attorney Does his family or somebody who knows him have money that they would give him for legal proceedings?

Addie Um, they have money but they wouldn't give it to him.

Ms. Attorney The reason I say that is 'cause sometimes parents, or grandparents, or other relatives uh have strong feelings and will loan a relative money to fight in court. And while it shouldn't make a difference, if you've got someone who has $\$ 20-30,000$ to fight something, and you're scraping by, sometimes the tactics that are used can make a difference. They c'-you can generate a lot of expenses.

Addie Well even the even the grandparents, they don't . see her . ever. [They (inaudible)] 
Ms. Attorney [Okay, I'm just, I'm] raising that just on the basis of experience, 'cause when you have a discrepancy in finances, sometimes it can become a pressure point. If for example, you're doing- taking all the money you can commit just to get it started, and he has got somebody who's gonna do lots of depositions and discovery, you can easily spend over $\$ 10,000$ before you even see the inside of a courtroom. So that's always a thing to keep in mind in the real world. How much money each side has. Um, What's he in jail for?

Addie Um I know it was something to do- um . something like forcing sex on a minor, somebody under the age of 14 .

This attorney has chosen topics based on the checked boxes on the Intake Form: parental termination, custody, adoption, name change. Had the attorney asked for a narrative at the outset, or focused on the short statement of goals on the Intake Form ("get parental rights taken away so my future spouse can adopt my daughter and get her name changed"), the attorney would have understood that the parental termination and the adoption were inter-twined. Once she realizes this, she interviews about the option of the birth father consenting to the adoption and explores advantages to that strategy. Here the attorney is offering the client two choices, but only briefly raises the pros and cons of the two different courses of action. This comparison leads to further questions relevant to the termination case - interests of relatives, costs of litigation, type of crime and length of sentence.

In discussing the costs of this proceeding it appears that the attorney is contemplating the client will hire an attorney to pursue this case, rather than proceed prose.

Next the attorney advises about various procedural matters: serving the father in prison, obtaining notice of transport for any hearing, proper jurisdiction and venue, that this is a civil case so the father would not be awarded an attorney, that a stepparent adoption is simpler than other adoptions that require "evaluations and investigations." This flood of information is probably more than the client can remember or needs to know. She concludes by characterizing a stepparent adoption as "fairly simple" stating: "You just need to get an Attorney that does stepparent adoptions."

Without missing a beat the attorney returns to interviewing about the adoption:

Ms. Attorney But you need to be married for a while first. Now does Jasmine know you?

Fiancé Yes.

Ms. Attorney Are you guys living together?

Fiancé Yes.

Ms. Attorney So she's used to you already. That'll help.

Fiancé Right, right.

Ms. Attorney Now, does she call you daddy? 
Fiancé Yes.

Ms. Attorney That's all in your favor. So when are you guys getting married?

Addie Don't know yet ha ha.

Ms. Attorney Okay, alright. Well, just know, that you have t- to ring the bell on that for - the last time I checked it was a year. I don't know if it's a year or three years. But you have to be married for a while. So the stepparent adoption is a ways down the road.

Fiancé Okay.

Here again, the lawyer is both interviewing (child's relationship with stepfather) and advising (the relationship will help), and providing more explicit recommendations ("ring the bell" on getting married).

It is of note that the attorney does not know the exact length of time the parties must be married before the stepfather can adopt, and admits that she does not know. In most of these consultations the attorneys admit they do not know something or are unable to predict an outcome. If it were important to give this client the precise answer, the lawyer could access the internet and read the adoption statute. Declining to get the answer but highlighting the issue in this way probably strikes the right balance between efficiency and efficacy.

The client's intake form had asked: "How can I go about this without hiring a lawyer." So, having already advised them to hire a lawyer, Ms. Attorney turns to this question and explores options with the client:

Ms. Attorney What else did you say? Uh... How do you go about this without hiring a lawyer? <laughs>

Addie Yeah.

Ms. Attorney The last time I checked there were not forms to terminate parental rights.

Addie Oh really?

Ms. Attorney You can go online if you want to. Utahcourts.gov. U-T-courts.gov.

Fiancé Right.

Ms. Attorney Or you could go to the front office is where the clerks are. Do you know where that is?

Addie No I don't.

Ms. Attorney Well you know how you came in the front and went through security?

Addie Yes.

Ms. Attorney If you turn half a circle right after you went through that, the last office is the clerk's office. And they're often very helpful. You could just go in there and say are there forms for terminating parental rights?

Addie Okay. 
Ms. Attorney And if the forms are there they'll tell you. They can't give you legal advice, but they're usually very knowledgeable about what forms exist.

Addie Okay.

Ms. Attorney The program's online, do you have access to a computer?

Addie Yes.

Ms. Attorney It's called OCAP, online court assistance program. That also has a list of all the forms that are there.

Addie Okay.

Ms. Attorney And when you get on the one form, it talks about once you, well different kinds of things. And I don't remember if terminating parental rights is its own category. There is a category for custody, but that's not what you want. And the other thing you need to know is that it's juvenile court, not district court. It's on the second floor of this building. It has its own set of judges, its own set of rules. And so those are the two things. Kind of a one-two process. Terminating the parental rights and then at some point in the future, a step-parent adoption.

Addie Okay.

Ms. Attorney Okay? Two different procedures. You want to know how to do it without an Attorney. There is a new thing that they have just started. It's called bundling and unbundling services. You don't have to hire a lawyer and pay a big retainer. What you can do is, for lawyers who do it, you hire them just for a specific purpose. Like, I'm not asking you to take on the whole case. I'm just asking you to draw up the initial papers. And so you can hire a lawyer just to do the first papers for you. Then if you want you can go back and just talk to that lawyer about what to do next if he answers or if he doesn't answer. So it's called unbundled services. So it's not exactly not doing it, not using a lawyer. But limiting how much you would have to pay. And so that's what you'd be looking for, is unbundled services. And they'll do just what you want, just draw up the first papers for terminating parental rights. Or draw up the first papers and giving you most of the steps that would be. Usually people who do it do it at the beginning and then if there's no answer, they'll hire the lawyer to draw up the papers at the end. That way you know it's getting done right, but you're not having to pay for a lawyer for all of that other stuff.

Addie Okay.

Ms. Attorney Okay, so that's as close as I can come to 'not hiring a lawyer.' I just don't think, you know, Jasmine's got so much riding on this, I don't know if you can do terminating parental rights without. Maybe, maybe you know what you want to do is consult a lawyer and ask the lawyer, 'Do you think we could do this ourself?'

Addie Okay. 
Ms. Attorney And see what the lawyer says. My opinion as a lawyer is 'no you can't.' But find a lawyer who disagrees. There are lots of good lawyers out there with different opinions. Or you might want to just hire a lawyer to draw up the first papers.

Addie Okay.

Ms. Attorney And give you a list of what would happen next.

Addie Okay.

Ms. Attorney Look into that unbundled services because that's usually, not always, but usually cheaper.

Addie Okay.

Ms. Attorney The reason I say not always is sometimes people wind up going back to the lawyer-one lawyer told me that she did a separate contract for each thing she did, and she'd done like 30 contracts and she said it would've been cheaper for the man just to hire me, but he felt more comfortable just having the lawyer do specific things. Like you can also hire a lawyer just to show up for a hearing.

Addie Oh [okay]

Ms. Attorney [Know] what I mean? So this unbundled services is fairly new. Uh, and I think people are-it's , it's kind of like an accommodation between trying to do it yourself and spending thousands of dollars retainer on a, a lawyer.

Fiancé Right

Ms. Attorney? So it seems to be meeting a need and so you might want to think about that.

Fiancé Okay.

This exchange makes clear that this attorney was approaching this consultation so as to give the client an idea about her legal rights and remedies, but not to instruct her on how to proceed pro se. All along, this attorney has been thinking the client will hire an attorney to represent her in this case.

While the attorney opines that she doesn't think the client will be able to proceed pro se, she does identify alternatives - asking the clerk or looking for on-line forms or hiring a lawyer for limited scope legal services. Giving the client these choices appears consistent with the literature about client counseling. She describes how unbundled legal services work and very concretely explains where to obtain forms (if they exist).

Ms. Attorney begins to wrap up the consultation by restating her advice marrying to pursue the stepparent adoption, when the client raises an issue that was in the Intake Form, but had not yet been discussed - changing the child's name.

Addie And then at that point can you get her name changed? The last name changed?

Ms. Attorney For a single parent you can do whatever you want. 
Addie Can I? Do I have to terminate the rights before I can change her name?

Ms. Attorney The last time I checked it's a policy in Salt Lake County. So you won't find the statute or regulation in Salt Lake County the last time I looked. If you're an unmarried mother, you can give your child any name you want to. Now I don't know, are you going to

Addie Yes.

Ms. Attorney Okay, I wouldn't change your child's last name until you get married.

Addie Right, okay.

Ms. Attorney [Inaudible] You could give your daughter about any name you wanted when she was born. You could call her Princess Bride or.

Addie Right, ha ha.

Ms. Attorney Or Princess Leia.

Addie Right.

Ms. Attorney So you can, you don't have to, I mean that's different. Unless you, did you sign some kind of an agreement with the father that you would leave the name the same?

Addie No.

Ms. Attorney Okay.

Addie Okay.

Ms. Attorney That you can do by yourself.

Addie Okay. Alright.

Ms. Attorney I'm sorry, is that good enough?

Addie Yes that's great.

Fiancé It works.

The Attorney provides some legal information that is not really germane (that a parent can select any name at birth), but interviews about the client's plan to change her own name upon marrying the Fiancé and advises to wait for that before changing the child's name. Perhaps because the attorney was focused on wrapping up the conversation, she does not provide the information that a name change is typically part of an adoption case.

This counseling session, too, was quite far-ranging. However, all of the issues explored - parental termination, stepparent adoption, name-change, custody and proceeding without an attorney - had been helpfully identified by the client on the Intake Form which the attorney clearly relied upon.

In this consultation the attorney never provided advice or information without first collecting relevant facts from the client through her questioning. This approach allowed the attorney not only to give the client the the standards that apply, but to highlight the facts that meet the legal standards. Typically the attorney would conduct further questioning as she was advising, so that the rhythm was "questioning, advising, more questioning, more tailored advising." 
This attorney also addressed strategic questions and included practical advice whether a custody case should be brought before a termination case (not in this case); whether the unwed father had money or family with money who would cause difficulties; that the client and her fiancé ought to marry promptly to move forward with this case; that they should wait on any change to the child's name until the mother's name is also changed through marriage; and that they should consider hiring an attorney for limited scope legal assistance.

This consultation was straightforward because it concerned a "new" case and because the case was a strong one. The consultation's strength was that it was personalized legal advice (not general information) based on sufficient questioning. Its minor weaknesses included the failure to learn about the interrelated issues through a client narrative and the inclusion of perhaps more information (e.g. naming rights at birth, service of process in prison, order to transport from prison for a hearing) than the client needs or will be able to remember and act upon.

\section{Enforcing/Modifying Vic's Visitation}

After 3 minutes and 20 seconds the attorneys began to give Vic their opinions that he was "doing the right thing." Further interviewing occurred followed by further attorney affirmation ("you're actually doing a really good job here" at 4:44) followed by further questioning, so the "counseling" portion of the consultation began at 5:28. At this point the attorney begins to explain that Vic may not be able to achieve his goal of eliminating the requirement for supervised visits through the procedural path he is on, but it is worth a try:

Vic So basically I need to know, do I need to hire an attorney for? Because like I go back on the $12^{\text {th }}$.

[I want to know]

Ms. Attorney 1 [Well here's what could happen,] here's what could happen. You could get in front of a judge and the judge could say "you know, you can't really do this by motion. What you really want, what you're trying to do is modify or change your decree of divorce. (hm hm) And so you need to file a petition to modify." So the judge may or may not let you do this by motion, does that make sense? Do you understand what I'm saying?

Vic Ok. So basically I'll have to [inaudible]

Ms. Attorney 1 [There's a possibility]. She may say (she may say) "oh you can do this by motion and I don't see why, you guys agreed to something and I don't see why we can't do it." But, under the rules, if you're going to change the decree of divorce, you do it by a petition to modify - that's a whole new pleading that you file with the court. And you have to pay-I don't know how much it is-it's probably like three hundred and some? 
Ms. Attorney2 Yeah something like that, like two fifty

[it's pretty expensive.]

Ms. Attorney1 [So with the petition] to modify you have to allege that there has been material change of circumstances--something has really changed (hmhm) since your divorce and that this supervised part should be taken off. So I'm not sure whether the judge will let you do that by a motion or not, but it's good to try.

Vic I've never had supervised visits, ever (Right) since we've been divorced, she's just dropped him off.

Ms. Attorney 1 And and that's certainly, and I think that's how you can probably get in [by saying]

Ms. Attorney 2 [Well and what's in] the divorce decree [though?]

Ms. Attorney 1 [Supervised] visits.

Vic Supervised visits.

Ms. Attorney 2 Ok

Ms. Attorney 1 But he's saying he [hasn't even]

Vic [I've never].

Ms. Attorney 1 got them

Vic I've never had them

Ms. Attorney1 So this is a motion to enforce visitation "and by the way judge, let's drop the supervised part." And I think she'll allow you to do that. So I think you'll be okay, if you want to, going on your own. You know, if you want an attorney to represent you, it's not a bad idea (Girlfriend: maybe if) but you seem to be doing pretty well.

Girlfriend So maybe if this doesn't work, (yes yes) and the judge says go back (yes) and

[then maybe look into it.]

Ms. Attorney 1 [Yes I would agree with that]

Vic 'Cause she had an attorney, then they just all of a sudden they just dropped it. We're sittin' there, and she didn't show up, but she didn't even call the court or nothing. Before I got there I literally called his office and ask him what happened. (MmHm) And she's just like well what's going to happen, and she's not comin' and so, therefore I thought I would win. But I didn't she she really couldn't, she said she's a pre-judge [because ]

Ms. Attorney 1 [Yes, she's] a commissioner.

Vic So she didn't get all the facts in, and I'm like, I gave her everything pretty much. So I just wanted to know, so you think I should just.

Ms. Attorney 1 I think you should run with it.

Vic Run with it?

Ms. Attorney 1 Yeah, just understand that it's possible that the judge could say at some point, you know, 'if you want unsupervised visits, you need to 
change your divorce decree. We're not going to do it by motion.' But you might be able to get in this way.

With two attorneys, the client, and his girl friend, there is a lot of over-lapping talk. In addition, the attorneys appear to disagree at one point. Both things may make this somewhat confusing for the client.

Nevertheless, this counseling segment seems effective. Attorney No. 1, the primary counselor, takes the tack of explaining what may happen in court by enacting what the judge might say. She is giving the bad news that this may be the wrong procedure through an imagined third person, the judge. The attorney also imagines that the judge MIGHT find the procedure acceptable, again quoting an imagined judge. Later the attorney provides the language that the client might use to argue his point, and finally concludes by again quoting the judge telling the client to use a different process. It would seem that the attorney's enacted dialogue would be helpful to the client in preparing for and appearing at the hearing.

The attorney also explains the difference between the client's chosen procedure (a motion to enforce the decree) with the technically appropriate procedure (a petition to modify the decree) by defining "modify" as "change" and by describing the "petition" as a "whole new pleading" that you file and have to pay filing fees. Ultimately the attorney suggests that the client go forward with the current procedure to see if the judge will be open to it, as the opposing party had previously agreed to eliminate the supervision during mediation and the opposing party had never actually enforced this provision in the decree. The girl friend appears to understand the advice, given her comments. The client, who has not been permitted to give a narrative, inserts his story that he has exercised unsupervised visitation and the story of the last court hearing when the opposing party and her attorney did not appear, but the judge (a commissioner) rescheduled the hearing instead of letting him win. (See italics.) These insertions appear to be driven by the client's need to tell his story and express his frustration. He ultimately returns to reiterate the attorney's advice that he should "run with it."

The girl friend then picks the next topic that deals with payment for supervision and then expresses her opinion about the inappropriateness of supervised visits.

Girlfriend Legally if she's requesting supervised visits, does she have to be the one to pay for it?

Ms. Attorney 2 [No]

Girlfriend [If it's] by her request?

Ms. Attorney2 No.

Ms. Attorney1 It's They both agreed to it. It's not just [her request. ]

Vic [No, I didn't] agree to it.

Ms. Attorney 1 Oh yes you did.

Vic See when I sign 
Ms. Attorney 1 [Yes you]

[When I signed]

Vic Yes, so I did

Ms. Attorney 1 Yeah. And it's silent about who, um, it says "all visitation shall be supervised by an adult at the sole discretion of (right) the petitioner." Well, but but she has to be reasonable. (mhhm) And if you've got a good family member, and if it's a very legitimate option then she should go for it. And the judge can compel her to. So I think you're, you're okay there. It doesn't have to be paid for, it doesn't 'shall have to' say 'it shall be supervised by a professional (mhhm) supervisor.' (mhhm) It just says by an adult. But it is in her sole discretion. But again, she has to be fair and reasonable. She can't just say well you'll never satisfy me so you'll never get visitation. It doesn't work that way.

Vic But this is what she's been doing.

Ms. Attorney 1 Right, and that's why you go to court.

Vic [This is wha]

Ms. Attorney 1 [You say,] "You know what, I don't like this supervised visitation. But I can work with it. Here's my dad. He's willing to do it." She even agreed to it.

Vic [She did]

Ms. Attorney 1 [The judge] is going to order it. I think.

Girlfriend And can he go in and claim, I mean, cuz really, I guess in my opinion, when you have a child and he's with his dad, it's not really normal to have somebody.

Vic [Cause he'd come for the whole weekend]

Girlfriend [tagging along 24 hours a day]

Vic Yeah, since I, since I signed that I

Attorney1 You can go back on a petition to modify it and say, "you know what, things have changed completely." (mhhm) You have to think about how things have changed. (mhhm) But maybe you were doing some things way back then that you're not doing now. (mhhm) Maybe there was a reason why she wanted supervised visits.

Vic Well that's what I'm saying, way back then there wasn't any problems. But when I acquired a girlfriend it was just all of a sudden, she just wanted to throw it out there.

Ms. Attorney1 Well anyway, I think you're definitely, this is the right approach.

Vic Okay.

Ms. Attorney1 Because you're saying "my dad can be the supervisor," (ok) so you're not now really trying to change things, you're just trying to enforce things.

Vic Yeah and she said this, I mean like, me in the mediation, she was like after three months I'll drop it [if everything]

Ms. Attorney1 [Yeah,] that's great. Then you two can agree to change your decree of divorce. It sounds like when she's actually brought into the room with a mediator she behaves well

Vic Yeah 


\section{Girlfriend Yeah}

Ms. Attorney 1 But when she's left to her own devices things get- You might actually want to bring her back to mediation and have her sign something right there, even handwritten, (mhhm) with a mediator there. $(\mathrm{mhhm})$ Don't wait until next week when she doesn't like you anymore.

Girlfriend Yeah 'cause that's what happened [inaudible].

Ms. Attorney1 M’kay.

Again there are multiple overlaps with the client, Vic, attempting to tell his story (see italics). Vic asserts he "didn't agree" with supervision, perhaps referencing his feelings about the necessity or appropriateness of supervision. The attorneys are both oriented to the legal fact of his agreement as expressed in the court papers. Vic comes to accept that as a legal matter he agreed to these terms. Ms. Attorney 1 reads the provisions of the decree and again shows Vic, through dialogue, how he might argue his case to enforce the decree with supervision by his father. Both the girlfriend and Vic return to argue the unreasonableness of supervision, with the girl friend asserting is it not normal to have supervision and Vic sharing that he had regularly had the child for the entire weekend.

This protest causes the attorney to return to the idea of filing a petition to modify the terms of the divorce decree based on the fact that "things have changed completely" and positing that maybe there were reasons for supervision in the past which have changed. This causes Vic to again try to tell his story -- "that's what I'm saying" alluding to his prior assertion that the child came regularly for the entire weekend without supervision, asserting that the only change had been his "acquiring a girl friend," and noting that the ex-wife had agreed to drop the supervision during the mediation.

The lawyers had previously failed to interview as to the initial reason for a request and order for supervision. Perhaps they took Vic at his word that he agreed to it to just get the divorce over with, or they thought it impolite to inquire about past problems in the presence of the girl friend. But the result is that Vic feels is not given personalized advice about how to prepare or argue a petition to modify. The attorneys advise him to "think about how things have changed" and neglect to tell him that the very fact that the ex-wife permitted unsupervised visitation for an extended period will suffice as a substantial change in circumstances justifying the requested modification. Here less thorough interviewing has unnecessarily lead to the lawyers conveying information about a modification rather than personalized advice.

The girlfriend further pursues the topic of filing a petition to modify by asking about fee waiver forms and whether the "household income" is Vic's income or their joint income.

The next topic is selected by Vic: whether he should have to pay for Montessori school tuition. 
Vic Then another thing about, what I go see, you know like my child support? She has him in private school. But I, you know, since I signed this, does that mean that I should be paying for the, I mean I pay child support plus the school. The school's like a private school so it's like a Montessori, so it's like $\$ 900$ a month.

Ms. Attorney 1 Let's see if it ... Child support, child support, insurance. In this divorce decree it might be too broad in general to state it..... You know, I don't think that this agreement, it doesn't look like you have the whole thing here. But, I don't think this is detailed enough to handle like private school and things like that.

Girlfriend 'Cause she enrolled him in private school and then [inaudible] then put it under the ORS so they're automatically taking that from his checking too.

Ms. Attorney 1 Well you know, I don't see .. I don't see anywhere in there that obligates you to pay half of educational expenses. They're in private school?

Vic $\mathrm{Mm} \mathrm{hm}$.

Ms. Attorney 1 It sounds like a choice that she made. You have to just kind of pour over your document and see, you know, you pay half the cost of the educational costs of the kids, then you do. (Mm hm) But if it doesn't say that you do, I would say hey I'm not up for this. And if ORS is taking it, then I would go to, make an appointment and take this with you and say it doesn't say anywhere in here that I pay for this.

Girlfriend I think it does say in there. But it says, 'cause I read through it, and it says that he pays half, but if she doesn't provide him with the information as to what school, where, then he's, he's not, he could be not responsible.

Ms. Attorney 1 Okay if that's what it says. You have to kind of look through.

Girlfriend And she hasn't done that. But if she does, then is it her discretion as to where he can go to school?

Attorney1 If she has legal, sole legal custody then she makes all the decisions. If they had joint legal custody, then they make the decisions together.

Vic Okay, so, so that means that if she has sole custody that means that uh, I have to pay for all the education? Half of it?

Ms. Attorney 1 If it's in here. And you think it is in there?

Girlfriend I think I did read that.

Vic It does say that she, she has sole custody.

Ms. Attorney 1 It does that, you know, you share

Girlfriend Out of pocket costs

Ms. Attorney 1 That's for insurance.

Girlfriend I think it was right around there somewhere.

Ms. Attorney 1 Well it does say-I know there's a provision for um, education costs, meaning like daycare relating to education.

Attorney2 Yeah.

Ms. Attorney 1 But I don't think that's it. I mean that's if she's going to school and she needs day care.

Ms. Attorney 2 Her share of child care expenses. 
Attorney1 Yeah child care expenses....What are the, yeah, okay there it is. Okay so "both parties shall share equally the work-related, career, or occupational training related child care expenses." And that means, you know when you get day care for your kid, you pay half of course. But it doesn't say you pay half of their private school tuition. That's what we're looking for now to see if there's a clause that says that.

Attorney2 Yeah.

Attorney1 These are [subcategories].

Attorney2 [These are all] childcare, huh.

Attorney1 And then there's life insurance, debts, see that's what, this doesn't seem to me like the type of document that's detailed enough to get into private schools. It's very stock.

Girlfriend So how would he go about getting that?

Attorney1 I'd go to ORS if they're taking it and take your thing (OK) and say hey it's not in here, why are you taking it out? (OK)

Girlfriend Yeah.

Attorney1 You do a motion in court just like you did here and say you shouldn't be responsible for private school when I didn't agree to be in my decree.

Girlfriend And maybe, I maybe the way she's, I mean cause it's pre-school so it's day care. But it's still a Montessori school I guess. I don't know if that's like.

Attorney1 Oh, so it is kind of like a daycare?

Girlfriend Well it's still private, it's still a private institution.

Attorney2 It's a Montessori pre-school that she has him in?

Girlfriend Exactly, exactly

Attorney2 So she's not dropping him off at someone's house to play with blocks all day. It's like structured educational environment.

Girlfriend Exactly, exactly.

Attorney1 I think it's not covered in your divorce decree.

Attorney2 Yeah it doesn't sound like it.

Attorney1 So I don't think you should have to pay for it. (Okay) Well I think we've pretty much covered it. Does it make sense?

Vic Yes.

Here the attorneys accept Vic's characterization ("private school") and attempt to answer his legal question by looking through the decree and without interviewing him about the situation. They forget there is just one child (referring to "they" and "kids") and do not interview about the child's age or explore whether this expense could be childcare for a pre-school child. Despite Vic's statement that "it's like $\$ 900$ a month" the attorneys do not explore what is $\$ 900$ a month (his total support? the total cost of the school? his share of the school expense?) or explore whether this cost is reasonable for child care. After reading the clause related to child care expenses they explain it: "And that means, you know when you get day care for your kid, you pay half of course. But it doesn't say you pay half of their private school tuition. That's what we're looking for now to see if there's a clause that says that." Vic doesn't volunteer that the "private school" is like "day care" and the attorneys do not 
interview him the school. As a result, they render an uniformed opinion that "private school tuition" is not covered in the decree.

It is only after the attorneys have advised Vic to file a motion to correct this charge that the girl friend shares how she thinks the ex-wife may be approaching the situation, explaining that it is a pre-school, "so it's day care." (See italics above.) As with Polly admitting to having violated the Protective Order, this is an example of the client's companion pressing bad but relevant facts on the lawyer so that the lawyer will be able to give the most informed opinion. ${ }^{42}$ The girl friend sharing this relevant and truthful information is consistent with philosopher Grice's maxims of cooperation in conversation.

The attorneys confirm the fact that it is a "Montessori pre-school" and "kind of like a daycare" but do not explore the costs, how they compare to other childcare institutions, whether the costs are incurred to allow the mother to work or go to school, or whether Vic knows of a cheaper child care alternative (such as spending parent time with him). Instead, they stay anchored to their previously stated opinion, even when confronted with the fact that this "tuition" is for a pre-school that is essentially high-quality day care.

Here Vic is not getting the same careful attention to detail and discussion of strategy that he received regarding his right to visitation. While he may have an argument that he is being charged too much, it is doubtful that a judge would eliminate the charge entirely where the mother needs the child to be in a preschool child care center while she works.

\section{ANALYSIS OF COUNSELING SEGMENTS}

In all four cases the attorneys turned to providing information and advice very early in the consultation ( 42 seconds, 2 minutes, 2 minutes and 40 seconds, and 5 minutes 28 seconds). Thereafter the dynamics of the consultations were brief questioning followed by advice on one topic then brief questioning and advice on another topic. The advice and information covered a broad array of topics in each case.

\section{Effect of Missing Narratives}

The lack of initial client narratives and insufficient questioning did create difficulties in some consultations, as became clear when the clients pressed their complete story on the attorneys.

The attorney advises Polly what to file, then discovers she had already filed the needed document. The attorney advises what to argue without knowing whether there is a factual basis for the argument. As the attorney is silently searching the

${ }^{42}$ See Smith, Client-Lawyer Talk: Lessons from Other Disciplines supra note 39 at 530-34. See Grice supra note 39. 
court docket, Polly volunteers very relevant and damning information (that she "was arrested for violating the protective order ... and ... spent a year in jail for it.") This information suggests that the attorney's prior advice to argue the Protective Order "isn't needed" will not have much success. But the attorney does not recalibrate to interview and adjust his advice accordingly. Polly comes away with the statutory language about dismissing protective orders, but not personalized advice about how to argue her case.

Similarly, Vic's attorneys appear not to understand his interjected narratives that his ex-wife regularly permitted him to have weekend long unsupervised visits, and has only insisted upon supervision since he has gotten a new girl friend. Nor do they interview to learn the alleged reason for supervision. Accordingly, they give him the general standard for modifying a divorce, but assert they don't know what has changed and fail to provide personalize advice about how to plead and argue a petition to modify. The attorneys opine that Vic should not be obligated to pay the Montessori school tuition before his girl friend reveals that it is a Montessori preschool "like day care." However, they fail to gather further information or to reconsider their opinion upon learning this important fact.

Polly's, Vic's and Vic's girl friends' desires to fully explain their situations drives home the importance of the narrative. It also illustrates the cooperative principle that the client will say as much as required and be informative on the topic. ${ }^{43}$

The other way in which the absence of narratives created challenges is the amount of overlapping talk and interjected explanations. Polly insists on a narrative while the attorney is looking up her docket. Vic often inserts brief narratives to explain himself in response to questions that only call for short or yes/no answers. Diane occasionally returns to the story she had shared on her Intake Form when the attorney's questions appeared to forget the crucial facts that her husband had abandoned and failed to support her and the children and they were left homeless. These examples show that the clients wanted to be understood. Allowing a narrative and remembering the facts shared in that narrative would improve not only understanding but rapport.

Only in Addie's case was the absence of a narrative not problematic, perhaps because her attorney always questioned before advising and uniquely provided personalized counseling rather than general information.

\section{Content of Counseling - Advice and Information}

In Addie's Step Parent Adoption case the attorney first advises about parental termination, then turns to step-parent adoption and then to name change.

${ }^{43}$ See Grice, supra note 39. Grice's cooperative principles are discussed in relation to legal interviewing in Smith, Client-Lawyer Talk supra note 39. 
Ultimately the attorney links them together from a strategic point of view, advising that it would be ideal to get the father to consent to the stepparent adoption in order to avoid litigating a parental termination case and that changing the child's name should await the client and fiancé's marriage. The attorney advises that the client need not first pursue a custody case. She also advises about hiring an attorney to provide limited scope representation, as it will be difficult to do these cases pro se. This attorney has learned sufficient information about the facts and goals to provide personal counseling, encouragement and strategic advice on each issue. However, she sometimes provide more information about the law and legal proceedings than is needed at this point.

Each of the other consultations involve some personalized counseling coupled with some legal information that may be useful for the client but could have been more personalized had further interviewing occurred.

In Vic's Visitation case the attorneys manage to explain the difference between enforcing an existing order and petitioning to modify the order, and advise strategically that the client should carry forth attempting to do both at one hearing, but warning that it may not be possible to modify the order to remove the required supervision without filing a separate petition. The attorneys explain that a petition to modify is an entirely new case, requiring court fees and a demonstration of a material change of circumstance but do not interview sufficiently to counsel Vic what to argue in such a petition. The attorneys model the dialogue of what the judge might say and what the client could argue at the upcoming hearing. This strategic advice and concrete demonstration seems particularly useful. This is a complicated situation, but the client and his girl friend take away a good understanding of the posture of the case and the ways they might need to proceed.

In Darla's Divorce the attorney provides a tour de force covering a dozen topics. The attorney identifies alimony as a possible goal and explains and illustrates how the need for alimony is assessed. Unfortunately, the attorney does not provide this same level of personalized counseling regarding child custody, which the sister had raised as a point of conflict. This counseling session includes a great deal of advice about HOW to go about doing something. The attorney's focus on getting the petition filed and bringing a motion for temporary orders seems entirely sensible in light of the client's lack of any support and concerns about custody and health insurance premiums. A nagging question is whether so much territory was covered that the client may be unable to remember or act on much of it.

Polly's Protective Order case includes almost exclusively legal information rather than personalized legal advice. The attorney tells her what to argue at the hearing, without exploring the facts to see what argument might be viable. He also informs her that she would need a criminal specialist to attack a criminal conviction, and the DA could charge perjury or violation of a protective order. It could be argued that providing this accurate legal information was the most sensible and respectful thing to do, as the client appeared to have little chance of success with any of these goals. 
The attorney is personally helpful by researching the case record as he discovers the notice for the hearing may not have been served on the other party, and emphasizes the need to do this. The attorney appears to recognize the client's emotional upset over not having seen her children, and volunteers that she could petition to modify the terms of the divorce decree if they had turned out to be unfair. It is possible that this client was seeking to vacate the protective order in order to be able to contact her ex-spouse to arrange to see the children, and the attorney was imagining this ultimate goal when he advised about the modification. It is unfortunate that the attorney did not initially explore the client's "real life" goals to understand why she wanted the Protective Order dismissed. Had that occurred, the consultation might have more usefully focused on the client's goal of reestablishing contact with her children rather than the instrumental goal of dismissing the Protective Order.

In very short periods of time (16 to 33 minutes), these attorneys interviewed, analyzed and provided both information and some personal and strategic advice to these clients on so many issues. Yet the tension between efficiency and effectiveness remains. Because so much information and advice was conveyed, one must wonder how much has been understood and will be retained by the clients. Although the attorneys did occasional ask if the clients "understood," they did nothing to test the clients' understanding.

\section{Structure of the Conversations}

The structures of the counseling conversations do not look like the client choice counseling contemplated in textbooks. The organization of the counseling is not anchored in describing two or more possible courses of action, predicting the consequences of each course of action, and weighing the pros and cons of each course of action.

Instead, much of the counseling involves explaining the one process the client needs to follow or the essence of the argument the client needs to make. Darla's attorney returned time and again to the need to file a complaint and then a motion for temporary orders. Polly's attorney emphasized the need to obtain service on the opposing party and the essence of the argument that the protective order "isn't needed." Vic's attorneys demonstrated how Vic should argue the visitation order be enforced and hopefully changed as well. In providing this advice the attorneys are thorough, work to define legal terms the client may not understand, and sometimes illustrate how the client might draft or argue a position.

While the conversations are not structured as choices amongst options, the attorneys often described options to the clients. Darla was invited to consider self representation, hiring an attorney, and seeking to have her husband pay the fees; Addie was invited to consider seeking forms or hiring an attorney for limited scope representation as well as seeking consent to the stepparent adoption rather than litigating a parental termination case; Vic was invited to try to proceed with his enforcement action but turn to a modification action if needed and to consider 
further mediation; and Polly was invited to consider filing a modification action to address the inequities she felt from her divorce. In these ways the counseling was client-centered and respectful of the clients' feelings and desires.

The clients and their companions did much to structure the consultations by posing particular questions in the Intake Forms and by posing even more questions during the consultations. "Here again, conversation analysis suggests that the client is as much in charge of the attorney-client conversation as is the attorney." 44 Yet these many client (and companion) questions contributed to extend and perhaps confuse the consultations.

\section{ENDINGS}

Some consultations end almost as abruptly as they begin. Others have a more extended ending.

In Polly's Protective Order case after the attorney counsels her that "it's not in vain" to bring a modification case to let your 17-year-old son know you want to have a relationship, he concludes: "Ok, so those are really your main issues. Let me take you down to show you those motions to modify." He is escorting her to the Legal Aid Office on site where forms are available. The entire consultation lasted almost 27 minutes.

Diane's Divorce consultation begins to end with the attorney asking if there are "any other issues" and the client's sister stating "No, It think you answered the main questions that we had to get her started. And if not, we'll be back on the next Wednesday." The attorney responds " $\mathrm{Ok}$ " then returns to further advise on the topic of hiring an attorney or proceeding pro se: "And if he goes out and gets an attorney, I'd strongly recommend you looking into it. I would still look into it as an option and see if it's a good fit for you. In some cases, you're just paying for convenience. And in some cases you're paying 'cause you really need an advocate too. Each case is different but tons of cases go forward without an attorney too, so." The client then asks one further question about fee waivers (if you don't qualify for Legal Aid could you get your fees waived?) to which the attorney responds that she doesn't "know the guidelines." Ultimately the attorney ends the consultation by offering to give the client the survey for this study. This consultation has taken the most time -- slightly over 33 minutes.

In Vic's case one attorney begins to end the consultation by asking Vic to complete the survey and the second attorney reflects Vic's goal. This provides yet another occasion for Vic's girlfriend to insert a small narrative about his circumstances. And this, in turn evokes further reinforcement, offers for further help and best wishes from the attorneys:

${ }^{44}$ Smith, Client-Lawyer Talk, supra note 39 at 510. 
Ms. Attorney 1 What's your last name Vic?

Vic Robbins

Ms. Attorney 1 Okay would you guys mind filling this out? (mm) And this is just, they're doing a study.

Vic Just to follow up?

Ms. Attorney 1 [Yeah.]

Ms. Attorney2 [Yeah] and the bottom line is you want to see your kids right? [You wanna see your kid, right?]

Vic [Yeah I mean it's been four months. It's ridiculous.]

Ms. Attorney 2 So, yeah you're doing the right thing.

Girlfriend He you know offered to be flexible whatever she wanted. He was totally an open book. He was like come to our house, see where we live, see our environment, meet my friends, meet whatever you want, like I'll be willing to do and she's just-

Vic Yeah, she just kind of blew me off.

Attorney2 Yeah, she's obviously not very happy with you.

Client 1 She wasn't happy.....

Attorney 1 [So]

Vic [What I] need to take this back over there?

Attorney1 What you do is you just put it in that pink box (ok) up there when you're done. And we're actually going to head back with another group (ok) right here. 'Cause I think there's room at the table. (ok) So I just want to wish you guys the best.

Vic Thank you I'm-

Ms. Attorney 1 I'm really [impressed with what]

Ms. Attorney 2 [And you guys know] when we're here, right?

Vic Just every Wednesday, right?

Ms. Attorney 2 Every other [Wednesday.]

Vic [Every other] Wednesday.

Ms. Attorney 2 It's the first and third Wednesdays, right?

Ms. Attorney 1 Yes. (ok) Hopefully you can [come back for some more input.]

Vic [Yeah so I'll come back after my court.]

Ms. Attorney 1 Well you're definitely doing the right stuff.

Ms. Attorney 2 Yeah.

Vic I'll let you know what happens.

Ms. Attorney 1 Alright and you've got a good judge. She's really nice.

Girlfriend She seems like it.

Vic [Yeah.]

Ms. Attorney 1 [She is.] She's smart.

Girlfriend We've been in there a couple of times.

Vic Yeah, she's kind of, woo. 


\author{
Ms. Attorney 1 Yeah [she is.] \\ Client1 [Ha ha.] \\ Ms. Attorney 1 But you know what, you guys will be fine \\ Ms. Attorney 2 Yeah, \\ [good luck.] \\ Girlfriend [Thank you for your time.] \\ Client [Thank you] \\ Ms. Attorney 2 [Good luck] you guys.
}

This extended goodbye with much overlapping talk is consistent with these attorneys having assessed this client's case as a strong one, and having given him advice as well as encouragement. In slightly over 19 minutes it seems a good attorney-client relationship had been forged. Yet the girl friend and Vic continue to try to tell their story (see italics above) portraying Vic as a reasonable person.

Addie's Stepparent Adoption consultation lasted not quite 16 minutes. The attorney initiates the ending by asking if her counseling had been adequate. Then she returns to the theme of St. Patrick's Day:

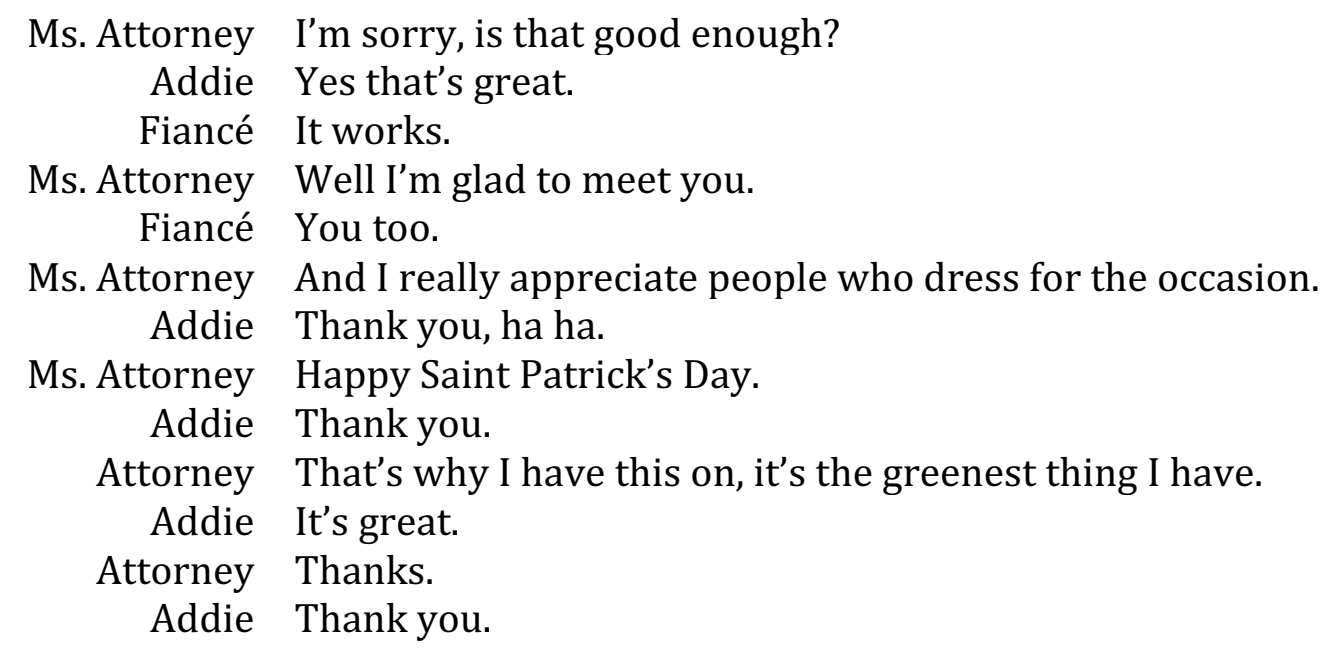

The multiple exchanges, laugher, Addie's "thanks" and "great," and the attorney's return to the ice-breaking topic also suggest that the consultation has been a positive one for this client and her fiancé.

\title{
VIII. CONCLUSIONS
}

This section moves from the descriptive conclusions set forth above, to more prescriptive conclusions for the attorneys and for brief advice clinics. 


\section{A. The Clients and their Matters}

The first point is that these were not "simple cases." They were not cases in which clients have chosen self-representation because the problem seemed too easy to employ a lawyer. Indeed, in three of four cases the consultation included a discussion of the benefits of having an attorney to handle the matter, and the ways in which the client might obtain an attorney, for example by having the opposing party ordered to pay or by pursuing limited scope representation. The complexity of these pro se cases raises serious questions about access to justice.

Secondly, these clients had many questions and wished guidance on a variety of topics. Sometimes these topics were related, as with Addie's Stepparent Adoption, which covered termination of parental rights, parental assent to the adoption, the adoption itself, name change and whether custody needed to be sought first. Sometimes the topics were only tangentially related as with Vic's desire to enforce/change visitation as well as not to pay the Montessori preschool tuition. Although clients typically had one pressing legal matter, they took the opportunity of a free consultation with a family law expert to ask about many issues. For example, Diane wanted to know "Anything about Divorce \& my rights" and sought or obtained guidance on a dozen different issues related to divorce.

Third, it was important to most of these clients to share their stories and to explain themselves. Two clients took the opportunity to tell heart-wrenching stories on their Intake Forms (Diane was abandoned by a husband who promised but failed to provide support, leaving her and her children homeless; Polly had been beaten up and lied about in court, and hadn't seen her children in three years). Three clients (Diane, Polly and Vic) orally inserted narratives during the consultations. Polly persisted in telling her complete story, ultimately sharing that she had been convicted of violating the protective order and spent a year in jail, making the attorney's earlier advice to argue the Protective Order "isn't needed" seem less than useful. Diane interrupted to return to the essence of her story when the advisor appeared to forget the crucial facts that her husband abandoned her and their children with no support. Vic regularly interrupted with the story of why he consented to supervised visitation in the first instance and that his ex-wife had never enforced the required supervision until he got a new girl friend. These clients' press to share their stories resulted in much simultaneous talk. Only Addie, who had no current legal problem but the desire to pursue a stepparent adoption, and whose attorney thoroughly questioned before providing advice, did not insist upon sharing her narrative and enjoyed a consultation with minimal simultaneous talk.

Fourth, all clients cared about how they presented themselves and shared facts and questions in ways that might save face. Both Addie and Vic chose to state only goals on their Intake Forms. Addie's Intake Form identified the goal of a stepparent adoption and did not recount "What happened" (the face-threatening facts that she had become pregnant with a loser who thereafter failed to support the child or form a relationship with the child, and who is now in prison for sexual abuse of a minor). Vic's Intake Form similarly identified "denial of parent time" and the goal of eliminating supervision in visitation, but did not tell the story of how supervision had come to be. This he saved for 
his many inserted oral narratives when he could portray himself as reasonable and his exwife as irrational. Diane and Polly both gave written narratives that presented themselves as victims. Diane orally returned to her narrative of having been abandoned with the children and no support when her right to custody was questioned or the attorney forgot she has no apartment. Polly's Intake Form identified herself as a spouse-abuse victim and told the story of having been beaten up and lied about, while identifying the goal of getting a protective order dropped, leaving it unclear that the protective order was against her. Ultimately Polly was able to tell a complete narrative, continuing to portray herself as the real victim in not only having been beaten up and lied about, but having been denied access to her children for years.

Finally, all of these clients brought companions with them to this consultation. They probably felt the need for support and wanted help recounting what had happened and remembering the advice. Nevertheless, the presence of a second person further complicated the consultations for the lawyers.

This combination of factors - the complexity of the cases, the range of issues, the clients' desires to tell their stories, the clients' desires to present themselves in the best light possible, and the presence of companions - resulted in these consultations being very challenging. As the clients and their companions tried to present their stories, their justifications and their questions, the attorneys no doubt felt as if they were drinking from a fire hose.

\section{B. The Attorneys' Interviewing and Counseling}

Because the clients' matters were neither simple nor unitary, a great deal of legal expertise was needed to diagnose the clients' situations and determine what advice and counsel to provide. These attorneys each knew a great deal about the law and local practice, and were able to provide both strategic advice and information on many of the issues presented.

\section{Discovering the Facts}

The attorneys relied on the Intake Forms, court papers, and short answer or yes/no questions, to speedily home in on the client's situation and what the client needed to know. In some cases, this targeted questioning allowed the attorney to learn enough to provide personalized legal advice (e.g. parental termination for Addie, alimony for Diane).

However, none of the attorneys asked for a client narrative. Polly's attorney finally listened to the complete narrative Polly insisted upon sharing while he looked up the court docket. Both Vic's and Diane's attorneys were faced with many mini-narratives in which Vic explained his rationale and Diane reasserted the narrative in her Intake Form. All three of these consultations involved simultaneous talk and interruptions where the clients pressed their stories upon the attorneys. 
Given the Clinic saw as many as 60 clients in a 2-hour period, and often had to turn away clients who had waited to we seen, the attorneys' desire for efficiency is understandable. Nevertheless, the amount of simultaneous talk itself suggests that there would be some merit in inviting a client to give a short narrative at the outset. Where the client has given a narrative in the Intake Form, as Diane did, the attorney should begin by reflecting her understanding of the situation recounted on the form and then turn to more targeted questioning.

\section{Exploring the Client's Goals}

In most of the cases the clients had shared their goals on the Intake Forms, and the reasons for the legal remedy sought (divorce, stepparent adoption, visitation) was clear. However, it was not immediately clear why Polly wanted to have the Protective Order "dropped" and the attorney did not explore this goal with her. As the consultation continued, it appeared as if the client was concerned about not having seen her children in years. Perhaps she believed the Protective Order was standing in the way of her being able to contact them. The consultation might have been more productive had the attorney explored why the client wanted the Protective Order dismissed at the outset. This may have lead to a discussion of other approaches to seeing her children, an issue only touched on at the end when the attorney advised her she could seek to modify her divorce.

\section{Providing Counseling and Information}

The attorneys were motivated to provide these clients with guidance as soon as possible. Accordingly, they turned to begin counseling within seconds to a few minutes.

This prompt pivot from interviewing to counseling had costs. Polly's attorney had already advised her what to argue to get the Protective Order dismissed before he learned the crucial fact that she had violated the order, and this argument would thus be very weak. Here he was providing legal information rather than personalized legal advice, and never returned to collect sufficient facts to help her prepare a convincing argument. Similarly, Vic's attorneys advised him that he could file a Petition to Modify the supervised visitation in his divorce decree, explaining that he needed to say there had been a change in circumstances but declining to explore what had changed. In so doing they appear not to have heard Vic's story that his ex-wife had willingly let him have the child for the weekends without any supervision, and only began denying unsupervised visitation when he "acquired a new girl friend." This in and of itself would constitute a significant change that would justify such a modification. Diane's attorney had the benefit of a short written narrative, but immediately began answering questions the client's sister propounded without any further questioning or analysis. The attorney failed to interview about the facts relevant to determine child custody. She failed to explain the standard for custody or advise Diane that she had a strong custody case, but instead warned that it would be difficult to proceed pro se if custody was contested. Here, again, 
the attorney failed to provide thorough counseling on an issue that appeared to be important to the client.

Although the attorney for Addie also began counseling quickly, she did so only after interviewing about the father's status, behavior, and relationship with the child. The answers to her ten or twelve questions allowed the attorney to conclude that the client had a good case to seek termination of parental rights. She helpfully explained the legal standard and identified the sort of evidence that would meet it.

The counseling was focused heavily on what to do and how to do it. In some ways this was necessary and useful. Vic needed to know how to argue his case in the near future, and his attorney provided him a model of what he could say, what the judge might say and what strategy he might then employ. Similarly, because Diane and her children were homeless and receiving no support, urging her to seek temporary orders (and to promptly file the petition so that the motion for temporary order could be filed) made sense. Polly's attorney helpfully looked up the docket for her case and discovered that the notice of the hearing may not have been served. This lead to his explaining the importance of seeing that service was accomplished. Addie was told to proceed with the stepparent adoption, and dispense with any custody case.

However, this focus on what to do and how to do it resulted in less emphasis on explaining the legal standard and how the facts of the client's situation would meet (or fail to meet) that standard. It was only in Addie's Stepparent Adoption that the legal standard and proof needed to meet it was emphasized.

Similarly, the counseling conversations were not framed as choices among optional courses of action. The attorneys occasionally and helpfully discussed different options. For example, Diane was told about Legal Aid, seeking private attorneys, and seeking to have the spouse pay attorneys fees; Vic was counseled about the difference between enforcing an order and filing a new petition to modify the divorce decree; Addie was advised that she could seek the consent of the father to a stepparent adoption rather than proceed with a possibly contested parental termination case. However, these choices among strategies were less prominent than the explanations about what to do, how to do it, and what legal standard would apply. It may be that the structure of a counseling session might include choices as appropriate, but be structured around "teaching" the client the law, the process, and how the law applies to the client's case.

Finally, one must comment on how much information and advice these attorneys attempted to convey in such short periods of time. This may be because the client (or her companion) posed a series of questions, as with Diane's Divorce and Polly's Protective Order. Sometimes the attorney identified strategic nuances, as with Vic's Visitation Enforcement/Modification and Addie's Stepparent Adoption. In some cases, attorneys raised legal nuances that did not need to be understood. For example, Darla's attorney explained that both Darla and her husband had legal custody, Polly's attorney explained that Polly was not defending herself but advocating for herself, and Addie's attorney described the fact that a parent could choose any name at birth. Sometimes the attorneys 
discussed theoretical approaches that would have no hope of success, such as Polly seeking a criminal law expert to vacate a criminal conviction and asking the DA to charge a witness with perjury. The attorneys would do well to limit discussion of irrelevant facts or hopeless strategies. Even so, one is left wondering if the clients will have understood and will be able to remember so much advice and information. They, too, must have felt as if they were drinking from a fire hose.

\section{Best Practices in a Brief Advice Clinic}

Based upon what we have learned from the fine-grained analysis of the four consultations, we are able to prescribe the following best practices for lawyering in a brief advice clinic and operating such a clinic.

\section{Intake Forms}

The Clinic should provide clients with an Intake Form and sufficient time to complete it. It should ask for both the client's goals and an account of what has happened. The Intake Form should ask the client to identify what type of legal matter the client believes she has and what steps the client has taken to address the matter. The Form may also ask the client to include written questions and identify the goals the client has for the brief consultation. A comprehensive Intake Form such as this may help the client focus and plan for the brief counseling session.

Attorneys should pay close attention to the written Intake Form that the client has completed, and use and reference it throughout the consultation. All of the attorneys relied upon the Intake Form to some extent, and the interview was improved when there was greater reliance and hindered when the attorney forgot what had been painfully conveyed in writing. The attorney should orally reflect to the client what she has learned from the form during the course of the consultation. Where the client has shared a narrative, the attorney should provide empathy or emotional reflection in response to that narrative.

The Intake Form is the client's opportunity to introduce herself and her goals. Accordingly, some clients will try to save face by declining to give an account of the problems that have developed. Some clients may list only goals and questions to avoid telling an embarrassing (or long) story in writing. Some clients will present themselves in the best light, even if that means being less than clear about the facts and goals. The attorneys should expect this and adjust their oral interviewing accordingly.

\section{Introductions}

In a brief advice clinic neither the clients nor the attorneys appear to need or benefit from informal chit-chat or ice-breaking. It is sufficient to engage in brief introductions. When there is more than one person, the introductions should include identifying the client or clients and the identity of any companions the client may have brought. 


\section{Companions, Confidentiality, and Privilege}

We have learned that clients often come to brief advice clinics with companions who are meant to help them. Companions may be there for moral support alone, or to encourage the client to ask all her questions, or to help the client remember all the advice. While the presence of a translator will not negate the attorney-client privilege, the presence of a such a companion will. ${ }^{45}$ With the increased use of brief advice clinic and limited scope representation, there may be merit in amending the rules of evidence to permit the presence of such companions without negating the privilege.

Although the presence of such a companion will render the consultation not privileged, this will rarely be an issue that actually harms a client. There is much merit in the approach Addie's attorney used - explaining the need to protect attorney-client privilege and thus the possible need to conduct some of the consultation in private without the companion.

Attorneys must seek strategies to ensure the companions are more help than hindrance. Addie's companion was usefully involved in the consultation and was the least disruptive, perhaps due to the explanation about privilege at the outset. The attorney will need to ensure that it is the client who directs the consultation and that any inhibitions or disruption that the companion creates are addressed by asking the companion to leave for at least part of the consultation.

\section{Interviewing - Including a Narrative}

If the client has provided a short narrative on the Intake Form, the attorney should indicate what she has understood about what happened. Further questioning or goal clarification should proceed from that point. Having a written narrative in hand should allow the attorney to select the topics for further exploration.

Often the client will not provide a written narrative on the Intake Form. In that case the attorney should ask that the client briefly describe what has been going on. Given that time is limited and the client will want to take away some actionable advice, the attorney may want to ask the client to "use five minutes" to share her account. Failure to ask for and listen to a client narrative will usually (in three out of our four cases) result in clients inserting narrative explanations when they are able. As these inserted accounts may be only partially responsive to the questions asked, the attorneys may not process what is shared (as appeared to happen in Vic's case). The absence of a client-directed narrative may also result in interruptions and simultaneous talk, also creating difficulties for the attorney trying to learn about the client and her matter. A brief narrative will be more efficient in the long run.

${ }^{45}$ See Rule 504, Federal Rules of Evidence. 
A client-directed narrative is also the best way for the client to be able to reveal negative or face-threatening information. It is important to have learned the negative information before beginning to advice so that the advice is applicable and so the client is not unduly embarrassed.

\section{Interviewing - Goal Clarification}

These clients were much more forthcoming and clear about their goals than they were about the facts. They shared legal goals (divorce, stepparent adoption) that made sense or real-world goals (get supervised visits taken off divorce decree). Three of the four clients did not need questioning to clarify their goals. When the legal goals make sense in light of the facts shared, goal clarification will not be necessary.

However, it would have been ideal for Polly's attorney to inquire further about her legal goal of dismissing the Protective Order. Asking "why do you want the Protective Order dismissed?" might well well have lead to a very different consultation about her desire to see her children and an exploration of approaches to bring that about.

Accordingly, the attorney should inquire about the client's ultimate goals when the client has shared only a legal outcome rather than stating what he wants changed in his lived experience.

Clients often come to brief advice clinics with multiple questions and various issues. The attorneys need to work to ensure the clients take away personalized advice they understand and are able to act on. Therefore, it could be wise to ask what the client hopes to accomplish in the 20 to 30 -minute consultation. If the attorney and client are able to agree upon a goal for the consultation, they may be able to focus on the most important or immediate issue and provide thorough personalized advice.

\section{Interviewing Before Counseling}

The attorney should interview sufficiently before beginning to advise. This can save time in the long run. Addie's attorney did not solicit a narrative, but asked a dozen questions before beginning to advise about the first issue. She consistently asked questions before providing advice. This consultation was the shortest, the most thorough, and included exclusively personalize advice rather than information. Diane's attorney was able to identify a claim for alimony by asking only one question (Do you have a big difference in your income).

These attorneys were oriented to discovering the status of the client's legal matter and determining what the client needed to know as rapidly as possible. To do this, they relied heavily upon the Intake Form and court papers. While this is efficient, it is often not sufficient. The attorneys need to ask enough questions to ensure that they are properly analyzing the client's situation and providing personal counseling rather than generic legal information. 
Vic's attorneys failed to ask about the Montessori school or the child's age, and thus provided an opinion that was not well founded. They failed to ask about changes in circumstances and thus provided only information and not personalized advice about custody modification. Diane's attorney never asked questions related to child custody, and thus provided no opinion as to the strength of Diane's custody case. Polly's attorney did not ask what had happened since the Protective Order had been entered, and thus told her to make an argument that is likely to fail.

Sufficient questioning will permit the attorney to give personalized advice rather than legal information that may or may not be germane to the client's situation.

\section{Personalized Counseling instead of Information}

Attorneys should resist the urge to provide general information about the law at the first opportunity. Volunteers with expertise may be tempted to lecture about the law. They should resist this temptation.

In Polly's case the attorney told her what to argue without interviewing to ascertain there was a factual basis for the argument. Once the client revealed negative facts, the attorney let the advice stand rather than conduct a thorough interview and give her candid advice about what might be possible. Similarly, Vic's attorneys reviewed the divorce decree and opined that Montessori tuition was not covered. Once the girl friend revealed the school was a pre-school "like day care" that failed to reconsider and adjust their opinions.

If the client responds to legal advice by sharing negative facts, the attorneys should reconsider the advice and probably conduct further inquiry. Otherwise the client will walk away with, at most, legal information that does not apply to her situation.

\section{Counseling as Teaching}

Counseling conversation(s) will typically not be structured as a discussion of different alternative courses of action, with outcomes of each alternative predicted. Instead, the counseling conversation will be structured more as if the attorney is the teacher, explaining the law and/or process to the client. The attorney's advice should include an explanation of the legal standard that applies and a discussion of how the client's facts meet (or fail to meet) that legal standard. The attorney will also focus on what the client needs to do and how the client needs to do that. Teaching the law and teaching the process is the most salient part of counseling in a brief advice clinic.

Where more than one approach or strategy is viable, the attorney should let the client know about the available options. However, this discussion of options will generally come later in some of the conversations, and may apply to only certain aspects of the client's matter, as we have seen in these cases (e.g. parental termination vs. consent to stepparent adoption). 
Attorneys should resist the temptation to explain all the law they know to the client. The client is not helped by information about the law that is not relevant to his particular matter. Including such information may make the attorney appear knowledgable, but it unnecessarily lengthens the conference and can add confusion for the client.

Similarly, attorneys should avoid lengthy explanations about approaches that have no possibility of success. The client should be candidly advised when this is the case.

Finally, the attorney-teacher should ask for feedback from the client to ascertain the client's level of comprehension. "Do you understand?" is not as useful as, for example, "Tell me what you plan to do next?" in learning whether the client is absorbing the advice and information.

\section{Exit Forms}

The attorneys and clinics should work to ensure that the client leaves with a clear explanation and identification of next steps, ideally in written form. The Exit Form should clearly identify what steps the client must take or forms the client should file. It should include referrals to other useful sources of information the client may need. The client should have a useful take-away so she won't feel as if she has been drinking from a fire hose.

\section{On-Going Limited Scope Representation}

Finally, because of the number of issues pro se clients sometimes present and the complexity of their matters, sponsors of pro se clinics should consider the possibility of on-going limited scope service. If such an approach was possible, the advisor could initially discover the client's situation and provide strategic advice about step one. Then, once the client had completed the first step, he could come back for instructions and advice about the next step. In that instance, the sponsoring agency or attorney would have a record of what had been learned and conveyed in the first consultation and would be able to provide more effective and efficient advice.

If these steps are taken, clients attending brief advice clinics should feel as if they are drinking from a forceful water fountain, but not from a fire hose. 